Article

\title{
From Silk to Digital Technologies: A Gateway to New Opportunities for Creative Industries, Traditional Crafts and Designers. The SILKNOW Case
}

\author{
Ester Alba Pagán 1,*(i), María del Mar Gaitán Salvatella ${ }^{1}$, María Dolores Pitarch ${ }^{1}{ }^{\circledR}$, \\ Arabella León Muñoz ${ }^{2}$, María del Mar Moya Toledo ${ }^{3}$, José Marin Ruiz ${ }^{3}$, Maurizio Vitella ${ }^{4}$, \\ Georgia Lo Cicero ${ }^{4}{ }^{\circ}$, Franz Rottensteiner ${ }^{5}$, Dominic Clermont ${ }^{5}$, Mareike Dorozynski ${ }^{5}$, \\ Dennis Wittich ${ }^{5}$, Pierre Vernus ${ }^{6}$ and Marie Puren ${ }^{6}$ \\ 1 Department of Art History, Universitat de València, Av. de Blasco Ibáñez, 28, 46010 València, Valencia, Spain; \\ m.gaisal@uv.es (M.d.M.G.S.); maria.pitarch@uv.es (M.D.P.) \\ 2 Garín 1820, Carrer de Ramon Villarroya, 15, 46113 Montcada, Valencia, Spain; aleon@garin1820.com \\ 3 EASD València, Carrer del Pintor Domingo, 20, 46001 València, Valencia, Spain; \\ mmoya@easdvalencia.com (M.d.M.M.T.); jmarin@easdvalencia.com (J.M.R.) \\ 4 Culture e Società, Università Degli Studi di Palermo, Piazza Marina, 61, 90133 Palermo, Italy; \\ maurizio.vitella@unipa.it (M.V.); georgia.locicero@unipa.it (G.L.C.) \\ 5 Institut für Photogrammetrie und GeoInformation (IPI), Leibniz Universität Hannover, Welfengarten 1, \\ 30167 Hannover, Germany; rottensteiner@ipi.uni-hannover.de (F.R.); clermont@ipi.uni-hannover.de (D.C.); \\ dorozynski@ipi.uni-hannover.de (M.D.); wittich@ipi.uni-hannover.de (D.W.) \\ 6 Laboratoire de Recherche Historique Rhône-Alpes (LARHRA), Université Lumière Lyon 2, 14, \\ avenue Berthelot, F-69363 Lyon, France; Pierre.VERNUS@msh-lse.fr (P.V.); Marie.PUREN@msh-lse.fr (M.P.) \\ * Correspondence: ealba@uv.es
}

Received: 10 September 2020; Accepted: 29 September 2020; Published: 8 October 2020

check for updates

\begin{abstract}
Nowadays, cultural heritage is more than ever linked to the present. It links us to our cultural past through the conscious act of preserving and bequeathing to future generations, turning society into its custodian. The appreciation of cultural heritage happens not only because of its communicative power, but also because of its economic power, through sustainable development and the promotion of creative industries. This paper presents SILKNOW, an EU-H2002 funded project and its application to cultural heritage, as well as to creative industries and design innovation. To this end, it presents the use of image recognition tools applied to cultural heritage, through the interoperability of data in the open-access registers of silk museums and its presentation, analysis and creative process carried out by the design students of EASD Valencia as a case study, in the branches of jewellery and fashion project, inspired by the heritage of silk.
\end{abstract}

Keywords: silk; cultural heritage; sustainability; culture creative; innovation; design

\section{Introduction}

In November 2013, in its Report on the Creative Economy [1], entitled "Widening Local Development Pathways", the United Nations showed its interest in contributing to the design of a new sustainable development agenda that recognizes the driving and catalytic power of culture. The report showed that creative economy is diverse and innovative and improves the local quality of life in developing countries. Among other examples, it highlighted that in the case of Argentina, the cultural and creative industries employ about 300,000 people and represents $3.5 \%$ of GDP. In Morocco, the publishing and printing sectors employ 1.8 per cent of the workforce, with a turnover of more than $\$ 370$ million. In Bangkok (Thailand), the fashion industry alone has led to 20,000 businesses 
of varying sizes, with numerous young people making a living as small-scale designers. The report also contains case studies on the Nigerian film industry (Nollywood) and the development of the home textile industry in Nantong (China). Culture is both a catalyst and an engine for sustainable development. It produces new ideas and new technologies that enable people to take responsibility for their development and stimulates innovation and creativity, which drive inclusive and sustainable growth. In this sense, creative industries can be understood as "those activities which have their origin in individual creativity, skill and talent and which have a potential for wealth and job creation through the generation and exploitation of intellectual property. These have been taken to include the following key sectors: advertising, architecture, the art and antiques market, crafts, design, designer fashion, film, interactive leisure software, music, the performing arts, publishing, software and television and radio in close inter-relationship with tourism, hospitality, museums and galleries and the heritage sector" [2]. Other authors [3-7] who have dealt with creative industries debate their implications for research and creative practice [8], as well as understanding them as the convergence between medial information services and cultural sectors for societal development [9].

On the other hand, cultural heritage is understood nowadays as a variable set of the cultural legacy that links us with our past. It is also a catalyst for innovative economies, through its connection with local and sustainable development and the promotion of creative industries. European history is woven in silk. Few materials have had such an economic, technical, functional, cultural and symbolic presence throughout our past and present: we can find silk in innumerable contexts, during most of the last 2000 years. However, its properties continue to be relevant for audiences that experience vivid, personal and social connections to this heritage, linked to other life stories and collective narratives, but, at the same time it offers an important flow for reflection and artistic creativity and design.

In this context, SILKNOW is a research project aimed at improving the understanding, conservation and dissemination of European silk heritage through the 15th to the 19th century. To this end, it applies computer, historical, artistic and geographical research to the needs of various users (museums, education, tourism, creative industries, media...) and preserves both the tangible and the intangible heritage associated with silk. Based on museum catalogue records, its goal is to produce digital models of weaving techniques (a "virtual loom"), through automatic visual recognition, space-viewing advanced temporal, multilingual access and semantically enriched with digital data, to preserve ancient weaving techniques, and at the same time to establish a space-line visual temporal of the historical evolution of silk textile design and establishing networks of artistic exchange, ideas and knowledge that occurred in Europe, as well as its trade routes and the economic impact on the territories [10-14].

Few cultural legacies bring together such a variety of materials, meanings, uses, traditions, innovations and creativity as the heritage associated with silk fabrics, as a bridge between our past and our present, but especially with our future through the development of creativity and design [15]. This is why silk heritage has a strong link with social innovation. The textile industry has a huge impact worldwide, accounting for more than $€ 1.63$ trillion of the global industry. The European Commission has recognised that fashion, particularly the textile, cultural and creative industries, are at the heart of the creative economy, generating enormous economic wealth, as well as preserving European identity, culture and values. In 2012, the European Commission (EC) officially promoted the cultural and creative sectors and in 2014 it published the Action Plan for Large Industries and Fashion, highlighting the important contribution of this sector to European cultures and economies. According to the European Clothing Confederation (Euratex), European textile and fashion companies are mainly Small and Medium Enterprises (SMEs) and directly employ 1.69 million people [16], 70\% of whom are women. Finally, the constant need for fashion, whether as a commodity or as a good material luxury, encourages innovation and experimentation in this field, being especially important in the traditional clothing linked to the heritage of silk, but also as an important source of inspiration and innovation for today's young designers [17]. In this sense, even today, numerous textile industries use looms that are inspired by ancient designs, using different techniques. In order that this heritage does 
not disappear, it is important to connect it with younger generations, weaving the past to promote the creativity of the future [12].

Relying on the community for the protection of its cultural heritage is fundamental since a community that is identified with its own heritage will protect it. Moreover, these values are renewed by each generation and are the result of continuous learning processes and are associated with the collective memory $[18,19]$. In this way, the enhancement of the cultural heritage together has social integration effects as it becomes a link between the various local actors in a territory [20,21].

In this paper, we show some of the results of the SILKNOW project, focusing on silk heritage from a double perspective, as heritage itself and as a creative industry. We will show the systematization processes of the European silk museums' cataloguists, the recognition of images and the work done with design students on fashion and other disciplines such as jewellery, specifically from Escola d' Art i Superior de Disseny de València (EASD) in València, one of the most prestigious design schools worldwide. We will also show its usability in the field of museums and creative industries from that double perspective: the knowledge of the past to build the future.

\section{Materials and Methods}

\subsection{Cultural Heritage and Innovation}

Social and cultural innovation strengthens the roots of European tradition and projects it into the future. The links between culture and economic growth, technology and social development are indisputable. Many international organizations have highlighted the role of cultural industries in social and personal development, show it to be the core of the so-called "global competitiveness" [22,23]. The UCLG (United Cities and Local Governments) [24] points out in its Agenda 21 that culture generates wealth and economic development. Furthermore, cultural heritage introduces ethical approaches and innovation linked to economic success and territorial competitiveness. Social innovation, which generates new forms of relations and governance, and technological innovation, which creates new products and services, are based on culture and heritage which act as raw materials to generate knowledge, creativity and value. The interrelationship between cultural heritage and innovation is therefore unquestionable as shown in Figure 1.
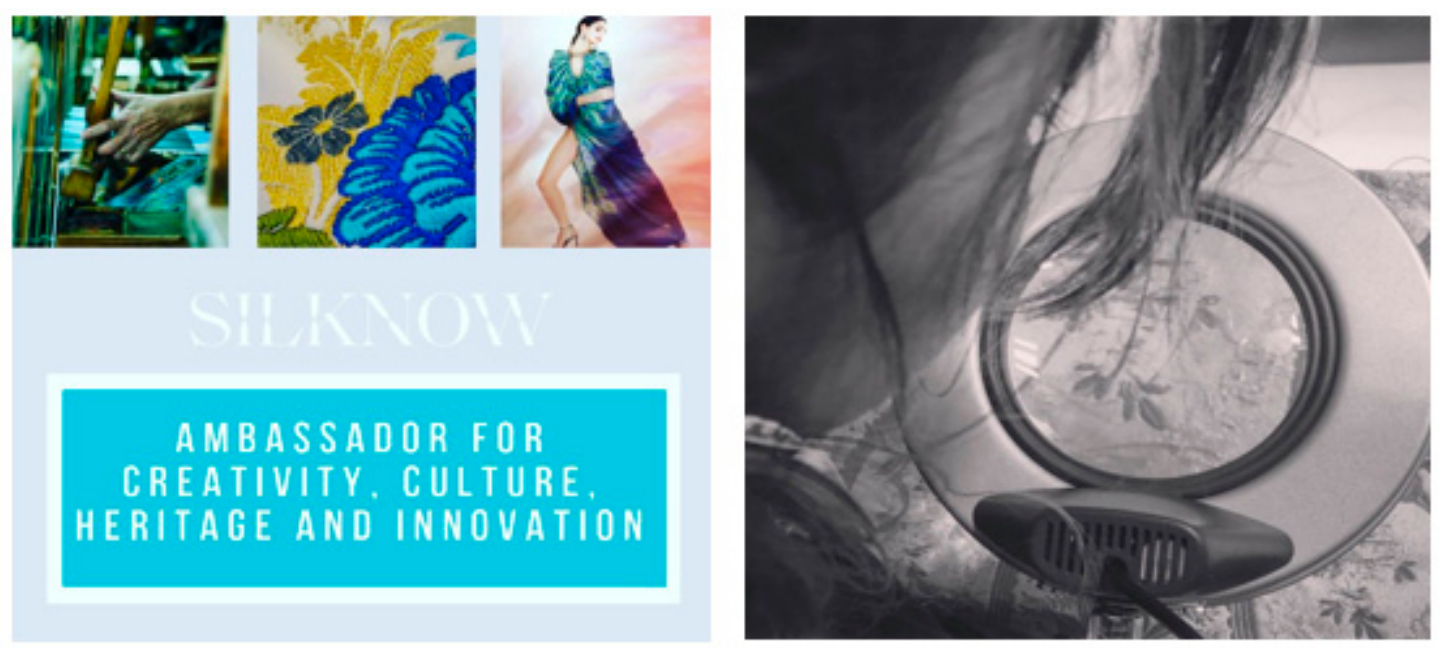

Figure 1. Conservator applying visual analysis to a silk fabric and SILKNOW digital dissemination.

There is a consensus in academia regarding the impact that culture has on the development of people and communities in terms of consolidating their individual and social identity, as well as the quality of life through the use and value in the market of cultural offerings in their broadest sense $[25,26]$. Along these lines, different authors have researched the capacity of culture as a creator of social dynamism and innovation in an inclusive and transformative way with positive consequences 
for society, such as the promotion of participation, the restoration or consolidation of identity, tolerance and social equity [27-29]. From this perspective, the cultural vitality of a society or territory has a clear impact on the improvement of the quality of life of the population, a quality that must be appreciated in aspects that go beyond short-term economic benefit, and that focus on elements that are difficult to quantify, such as personal satisfaction and happiness. These elements are drivers of creativity and innovation, consolidating local social capital based on shared leadership and governance that give rise to a beneficial circle which, in turn, generates a greater appreciation of culture and heritage.

SILKNOW can be understood as an innovative project and a catalyst when valuing and promoting silk heritage, linking it to innovation and creativity. SILKNOW not only aims to preserve, protect and communicate the historical legacy of silk as well as its evolution from the applied arts and product design in multiple contexts, but also, with a strong view of the future, it pretends to serve as an enabler of creativity and innovation through museum silk collections and their promotion thanks to open access and digitization. Therefore, silk designs and their importance in the historical, social, artistic and economic construction of Europe are made known at the time they can be a reference for future generations, as well as an economic and sustainable development engine for creative industries and young designers.

The digital era has led to a wide range of tools at the service of documentary and creative collections-more specifically in the field of conservation and innovation-that will better conserve, manage and disseminate heritage. This has come from extreme need, especially when making the museum's collections intelligible to the entire society and from an inclusive perspective is already a must, furthermore, considering that culture is a universal right. Besides, information technologies arise as fundamental allies in the transmission and preservation of collective memory, particularly in disseminating values that promoting knowledge through the advocacy of tools capable of acts such as an engine of innovation and sustainable development of the economic and productive sector associated with design.

\subsection{An Innovative Way of Preserving the European Regional Silk Heritage}

As mentioned, European history is woven in silk. Common ideas about the Silk Road are most often limited to its ancient and Asian origins, ignoring the importance of its later European ramifications. There is, however, an increasing interest in the Western Silk Road, the network of production and market centres, spreading over various European countries, that this project aims to make better known. It encompassed aspects as diverse as trade, science, craft, art, diplomacy and culture. European silk heritage can be defined as integral heritage, it is both tangible and intangible, history and present culture, crafts, traditional knowledge and industry and, above all, living heritage like in Garin's industry that has 200 years of history (Figure 2). Few objects bring together such a variety of materials, meanings, uses, traditions, innovations and creativity as it happens as silk fabrics. They are a bridge between our past and our present, but especially with our future through the development of creativity and design.
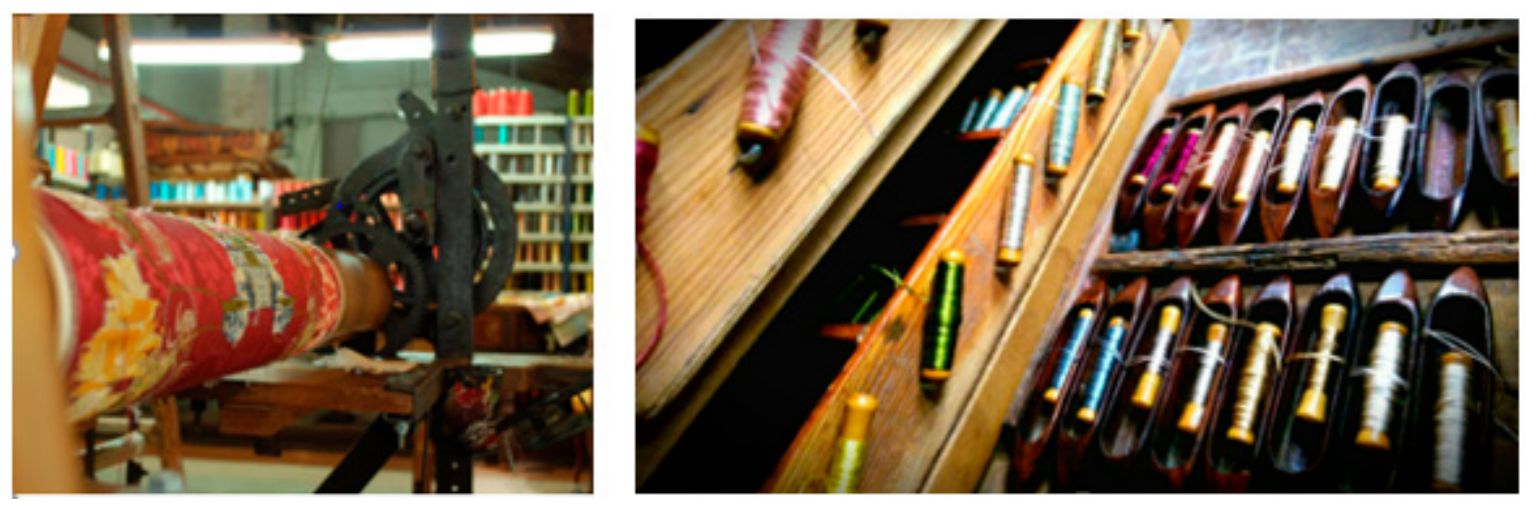

Figure 2. GARIN 1820 atelier. 
Silk fabrics are present in the great European national collections, and important museums preserve important historical material testimonies: among them the Metropolitan Museum, Victoria and Albert Museum, Museo del Traje, Museo Nacional de Artes Decorativas, the Musée d'Arts Decoratifs, or the Abbeg Fondation, Museo Nacional de Cerámica y Artes Suntuarias González Martí etc. It is also present in European archives and libraries which guard an ancestral history, knowledge, techniques, trades, commercial routes and institutional history, in most of the historical archives, or other specialized archives such as the archive of the Colegio Arte Mayor de la Seda of Valencia or the Centre de Documentació i Museu Tèxtil of Terrassa (Barcelona), French national archives, municipal archives of Lyon and Saint-Etienne, archives of the Rhône and the Lyon metropole, of the Loire, Vaucluse or Gard departments in France. Silk is also part of ecclesiastical collections, from the Musei Vaticani to several diocesan museums, as well as the ethnological collections. Moreover, silk heritage can be found in many small and medium cultural institutions.

Nowadays, however, silk textiles have become a seriously endangered heritage. One reason lies in its very physical nature; it is more fragile than other, more conventional cultural assets (painting, architecture, sculpture, etc.) Although many European specialized institutions are in operation, they usually are small or medium in size, and lack the resources to develop state-of-the-art digital resources. Besides, historical weaving techniques are in danger of disappearing with the imminent closure of companies that still use looms and old machinery today. Nevertheless, their actions are still linked to many life stories and collective histories. These old industries preserve a rich cultural heritage linked to industrial processes: looms, machinery and creative processes: drawings, point papers and catalogues.

In this context, SILKNOW [14] is a research project that aims to improve the understanding, conservation and dissemination of European silk heritage from the 15th to the 19th century. This legacy is studied, showcased and preserved through the digital modelling of its weaving techniques (a "Virtual Loom"). Users can access the resulting information through visual and tangible simulations, and experience vastly enhanced search tools, providing better results through automatic visual recognition, advanced Spatio-temporal visualization, multilingual and semantically enriched access to existing digital data. Thus, SILKNOW improves the understanding of European heritage and its rich diversity, applying next-generation ICT research to the needs of various users (museums, education, tourism, creative industries, media ... ), and preserving an intangible heritage (historical weaving techniques) for younger generations. Its research activities and outputs will have a direct impact on computer science and big data management, focusing on searching digital content in heterogeneous, multilingual and multimodal databases. We can affirm that cultural heritage and technology are united in an interdisciplinary gaze that is gaining strength. Digital access can serve as a mediation to integrate citizens in the challenges of heritage and its preservation. This contributes to the understanding of cultural heritage diversity and the socio-cultural reflection connected to historical, artistic and cultural dimensions. Anna María Guasch [30] defends that the processes of globalization, such as the consolidation of new technologies, and the changes in communication and access to information have allowed the widening new horizons. This allows us to connect with other cultures, other realities, other societies, etc., establishing bridges between diverse local realities, connecting and generating new networks, allowing a wide multiplicity of "dialogical experiences" [31].

\subsection{Cultural Heritage and Creative Industries}

For UNESCO [1], cultural and creative industries related to cultural heritage are: "those sectors of organized activity which have as their main object the production or reproduction, promotion, dissemination and/or marketing of goods, services and activities of cultural, artistic or heritage content". This approach emphasizes both the materiality, that is, the object, as an end-product of a creative or artistic process, as well as the channels of diffusion or the design process itself. Far from facing a homogeneous world, the kaleidoscope ranges from industrial processes to handicrafts, traditional knowledge and art. A set of realities whose main challenge is to strengthen local capacities, access to 
international markets, protect and preserve their cultural heritage, and the defence of intellectual property. To this end, it is first essential to understand that the conservation of this fragile cultural heritage, especially those linked to processes, historical techniques and traditional knowledge, requires proper management. Cultural heritage should not be understood only for its economic value, but also for its capacity to communicate inherited meanings. Making society know and appreciate its cultural heritage and feel like it is its own, means making heritage intelligible, which in turn will lead to the development of true awareness, cultural heritage protection and will turn it into an innovation agent [32]. However, even if UNESCO puts creative and cultural industries at the same level, there is no unanimous consensus, but rather a broad discourse on it [33]. Recent studies differentiate between cultural and creative industries, as well as challenging the traditional hegemony of cultural industry indicators proposed by UNESCO. In this sense, they argue that the transition from cultural industries to creative industries has highlighted the importance of redefining the system of indicators to monitor and measure the impact of an increasingly dynamic and complex sector [33]. But beyond complex conceptual theories, it is undeniable that cultural heritage in its diversity offers a wide range of possibilities for social development, while its appreciation and usability is a guarantor for its protection and the promotion of the expression of cultural diversity [34]. Concerning European silk heritage, the inclusion of several European cities in the International Silk Road [35] has demonstrated an eager interest in this legacy that has long been part of historical, artistic and heritage research (Figure 3). In this regard, some interesting initiatives have emerged to consolidate or promote the close relationship of this heritage and its intangible and creative dimension with cultural and creative industries.
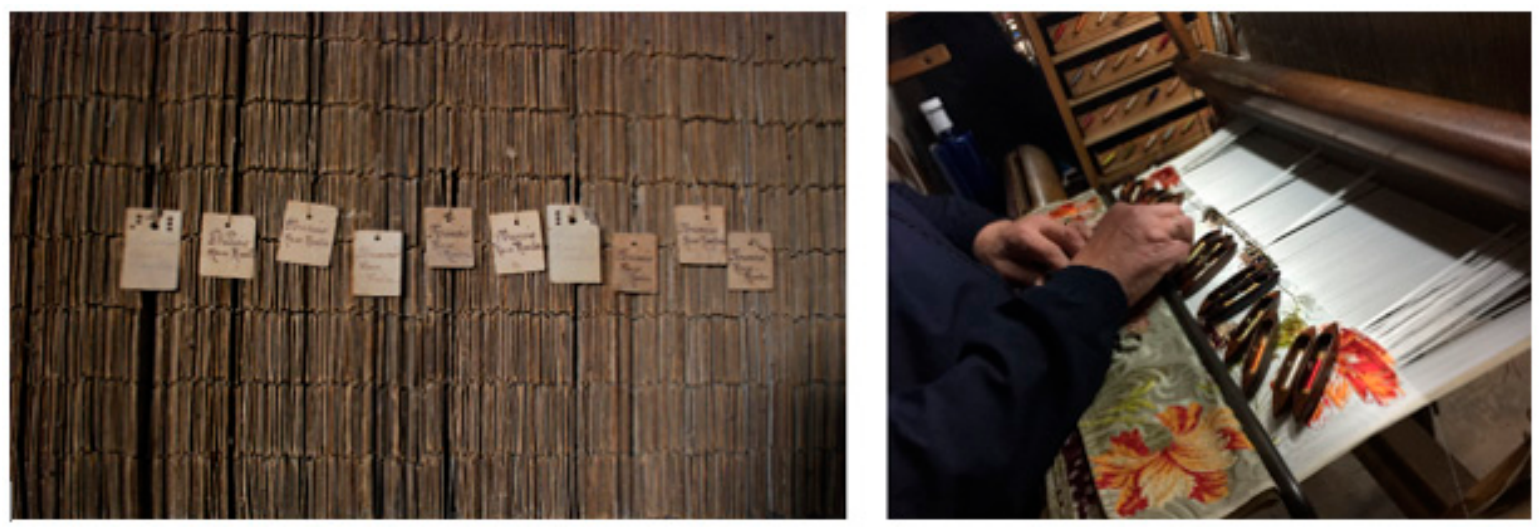

Figure 3. GARIN 1820 atelier: tablet weaving and silk weaver using a brocading shuttle.

The issues associated with creativity in the economic sector are starting strongly, in the Anglo-Saxon context, with the publication of the Creative Industries Mapping Document (Department of Culture Media and Sports [36], and the success of Richard Florida's book The Rise of the creative class [37]. However, the term "creative industry" is developed on the Australian territory with the report Creative Nation: Commonwealth Cultural Policy [38], subsequently extended to European institutions [39] and the United Nations $[40,41]$ These reports argue that the traditional artistic sectors (scenic arts, plastic arts, cultural heritage-including the public sector) also include cinema, DVDs and videos, television and radio, video games, new media, books and the press" [42]. While creative industries are understood as those that use culture as an input and have a cultural dimension, their outputs are primarily functional. Therefore, they include architecture and design, which integrate creative elements throughout their processes, as well as subsectors such as graphic design, fashion design or advertising. At a more peripheral level, many other industries are related to the production of content for their development, hence they are somewhat interdependent with cultural and creative industries. These include the tourism sector and new technologies [43]. 
In this sense, it recognises a central sector, whose value is not only economic and where visual arts (painting, sculpture, photography and handicrafts), stage arts (theatre, dance, circus and festivals) and cultural heritage (museums, archives, libraries and archaeological sites) are integrated.

On the other hand, the report by KEA European Affairs, [44] requested by the European Commission (Directorate-General for Education and Culture), made clear the great economic importance of culture, from where creative industries emerge, insisting that cultural and creative industries not only have a direct impact on the economy but also have an indirect impact, through economic sectors (ICT, tourism, education, etc) on which some cultural and creative activities have a positive impact [41]. In 2009, the creative industries sector accounted for 4\% of GDP in Europe, reaching $8 \%$ in some countries such as the United Kingdom. The billing of European creative industries amounted to 654 billion euros in 2003, growing 12.3\% faster than the total European Union economy and employing 5.6 million people. World trade in goods and services in the creative industries grew by an average of 8.7 per cent annually from 2000 to 2005, according to figures provided by the United Nations Conference on Trade and Development (UNCTAD), reaching $\$ 445.2$ billion in 2005 [45]. In its 2013 report, the UN established the strong link between creative industries and development through the momentum they exerted on local economies [1]. Co-published by UNESCO and the United Nations Development Programme (UNDP) through the UN Office for South-South Cooperation, the Report was launched at the UNESCO General Conference and its ambition was to contribute to the design of a new and ambitious post-2015 sustainable development agenda that recognizes the driving power and catalyst of culture. This report on the creative economy, entitled "expanding development channels at the local level", stated that global trade in creative goods and services had reached a record level of $\$ 624$ billion in 2011. Growth doubled between 2002 and 2011, while affirming that creativity and culture contribute to inclusive social development, dialogue and understanding among peoples: "In addition to creating jobs, the creative economy contributes to the overall well-being of communities, promotes individual self-esteem and quality of life, leading to sustainable and inclusive development. At a time when the international community is designing a new post-2015 development agenda, it is vital to recognize the importance and power of the cultural and creative sectors as engines of development", according to Irina Bokova, Director-General of UNESCO.

To this must be added the fact that the creative and cultural industries sector has demonstrated broad resilience in adverse times and job creation, given it its dynamic and innovative nature. In fact, according to Eurostat data published in February 2018 and for 2016, there are 8.4 million jobs in the cultural sector, $3.7 \%$ of the employed population. Moreover, the trend that can be seen from the data of recent years is upwards. Compared to 2011, data for 2016 show an increase of 549,000 jobs (an increase of $7 \%$ ) in the European Union. Neverthles, several challenges are recognised, including the small size of enterprises, problems of access to finance, lack of business networks and collaboration between different companies in the sector [46].

The shift between traditional cultural approaches and the new vision in the promotion of creative industries was already consolidated towards 2010. The EU adopted the European Agenda for Culture in 2007, which ran until 2013. In 2010, it published the Green Paper on Culture, which served as the basis for the design of the Creative Europe 2014-2020 programme, which was approved by the EC on 23 November 2011 and is currently in force. This programme is part of the new European innovation policies (Union Innovation 2020), which fully recognises the importance of the cultural and creative sector (SCC) for innovation and its growing economic weight and strategic status for the future of the Union $[17,33,47]$. In the field of the creative economy [48] associated with cultural heritage, studies focus on accounting for the property of cultural interest both movable and immovable, and in recent years elements have been recognised as intangible property, leaving aside the many goods that are not classified as exceptional or unique, but standing out for their local relevance or for being included in general inventories, among which the popular cultural assets stand out in particular, industrial and urban heritage, landscapes or contemporary cultural production [49]. John Howkins proposed the term "creative economy" to include the following industries: advertising, software, 
architecture, art, crafts, design, fashion, film, music, stage arts, publications, Research and Development, toys and games, broadcasting and video games. On the other hand, the economic importance of heritage is measured both in the investments made by public administrations in the conservation of this heritage and in its value as a fundamental resource of cultural tourism [50], without establishing a real connection between cultural heritage and its contribution to the creative industries, from the prism defended here. However, the weight of creative industries in Spain is highly significant: $22 \%$ of the Spanish working population is part of the so-called "creative class" and 5.7\% of Spanish production originates in the "creative industries" [51].

For its part, UNCTAD in its report [40] integrated cultural industries into creative industries, considering the former as a subset of the latter, so that the UN established four concentric circles: a core of creative arts: Literature, Music, Stage Arts and Plastic Arts; Other Nuclear Cultural Industries: Cinema, Museums and Libraries; Wider Cultural Industries: Heritage Services, Publications, Sound Records, Television and Radio, Video and Video Games and related industries: Advertising, Architecture, Design, Fashion. A debatable model in its organization, in which, surprisingly, handicrafts are not included in the culture group [33].

The report on the creative economy of the United Nations also maintains that creativity and culture are processes or attributes that are closely linked to the imagination and the generation of knowledge and the various ways of seeing and interpreting the world. It is therefore essential for human development through the conservation and management of cultural diversity, including tangible and intangible cultural heritage. To this end, the report outlined ten recommendations, recognizing that in addition to its economic benefits, the creative economy generates a non-monetary value that contributes significantly to the achievement of inclusive and people-centred sustainable development:

- making culture an engine and facilitator of economic, social and environmental development processes;

- revealing opportunities by identifying the assets of the creative economy;

- improve the information base by undertaking rigorous data collection as an essential preliminary investment for the adoption of coherent policies for the development of the creative economy;

- research on the connections between the formal and informal sectors to design policies for the development of the creative economy;

- analyse the crucial success factors that contribute to opening new channels for the development of the local creative economy;

- investing in creativity, innovation and creative enterprise development;

- investing in capacity building at the local level to empower cultural creators and entrepreneurs, government officials and private sector enterprises;

- engaging in South-South cooperation to facilitate mutually beneficial learning and inform international development programmes;

- positioning culture in local economic and social development programmes, including competing priorities.

This process advocated the innovative and diverse nature of the creative industries and their potential as an engine of quality of life at the local level, by fostering innovative and sustainable growth. The UN report certainly provided an important incentive for reflection and the establishment of new development policies based on culture and creativity. Although conceptually the structure proposed by KEA, applied by the European Commission, is somewhat more rigorous, although certainly improving as the cultural heritage focuses on the institutional sphere (museums, libraries, archives and archaeological sites) and does not take into account other heritages such as the intangible one, particularly significant in the field of handicrafts, remaining limited to the spectrum of the visual arts, and therefore to their materiality. 


\section{Results}

\subsection{The Cultural History of the Silk Industries in Europe: The Case of Spain, Italy and France}

Silk has shaped international routes, such as the Asian Silk Road, and later, particularly thanks to trade networks in Europe, the European Silk Road, both demonstrate the importance that silk had in the construction of world history (Figure 4 shows Silk in Valencia and in France). At the same time, it also maintains a common collective narrative among the various centres of European silk tradition, such as France (Tours, Lyon, Saint-Etienne, Nîmes, etc.), Italy (Bologna, Genoa, Lucca, Turin, Florence, Venice, Como, etc.) and Spain (Toledo, Granada, Seville and Valencia). These relations between European territories have been evident since the middle ages. From Southern Italy, mulberry began to spread in Europe in the late 14th century. The obtention of silk fibre involved all members of a family unit as it required specific tooling and infrastructure in rural housing; it provided a vital income to cope with the burdens on peasant farms, and required the hiring of a relatively skilled workforce for their processing [52,53], which turned into a whole series of related trades: twisters, dyers, weavers, etc. Since the 13th century, important Italian silk workers could be found in Lucca, Florence, Milan, Genoa and Venice, who later migrated and eventually, lead to large textile centres of first magnitude such as Lyon whose diversified and innovative designs will be inherited in other industries like the aforementioned Valencian industry [53].

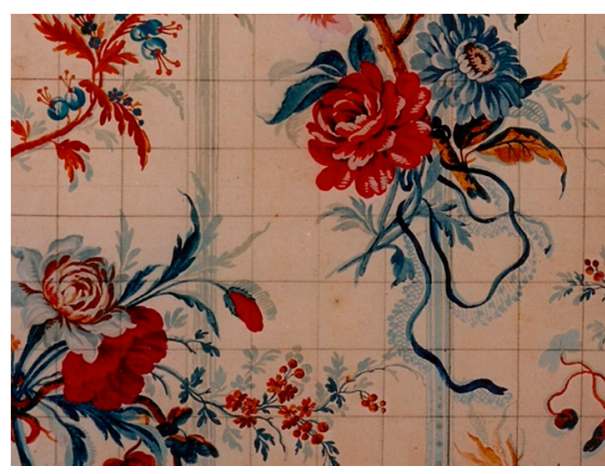

(a)

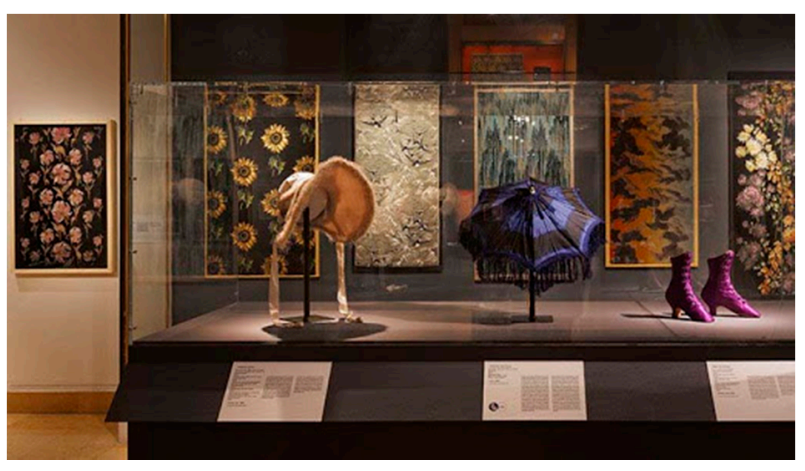

(b)

Figure 4. (a) Benito Espinós (1748-1818). Fabric model. Gouache on laid paper, squared for weaving, Museo de Bellas Artes de València. (b) Musée des tissus de Lyon, France.

Traditionally, the 18th century is considered the golden age of the European silk industry [52,53], with Lyon being the most important centre in textile production. Lyon's predominance is the outcome of a long process. The fairs, established in the 15th century, made Lyon one of Europe's main commercial and banking centres. Their success was based on Italian merchants who made Lyon the great re-export market for Italian silks and the gateway for Italian silks to France. For fear of displeasing the Italian merchants, Lyon authorities refused the king's proposal to establish a silk fabric manufacture in 1466. However, a few decades later, in 1536, they supported the initiative of Italian merchants to whom Francis I granted the privilege of manufacturing gold, silver and silk fabrics. This initiative was emulated, and production increased but remained fragile. After the political and economic crises of the last third of the 16th century, production experienced long-term growth in the 17th century. The invention of the métier à la grande tir by Claude Dangon in 1605, its diffusion and improvements encouraged by "public management of invention", enabled the Lyons weavers to move from the production of plain silks to that of shaped silks, then gradually to compete with the luxurious Italian patterned silk fabrics and, in the 18th century, to impose their pre-eminence on international markets. This pre-eminence and the ability to dictate fashion trends was based on a strategy of programmed and systematic renewal of production which imposes competition based more on product differentiation than on price, a decline in the average quality of the fabrics, not exclusive of maintaining high-quality production but which makes it possible to win new customers. Thus, at the end of the 18th century, 
silk fabric production and related activities became the driving force of the Lyon economy, and it is estimated that they employed more than 60,000 people for a population of 150,000 inhabitants. The growth of Lyon's production favoured the expansion of sericulture in the south-east of France and the importation of Italian silks. This story is similar to what happened in Valencia where these close relations between Valencia and Genoa allowed to improve its silk industry and thus create the famous district of Velluters. It was during the 18th century when the city of Valencia became a first order manufacturing centre, toppling Toledo, which was the main centre of Spanish [53]. A history that is intertwined with the implantation of the Real Colonia Serica di San Leucio, a royal silk factory that King Fernando IV, son of Queen Amalia and Spanish King Carlos III of Bourbon, was erected in 1778 not far from the royal palace of Caserta (Naples), whose history remains within the Monumental Complex of Belvedere (recognized by UNESCO as a World Heritage Site). This factory remained in operation until 1861 when, after the invasion of the Savoy, the Kingdom was annexed to Piedmont and the silk factory was privatized. This was how the factory workers decided to open small family businesses, which remain a reality under the Consorzio San Leucio Seta: Setificio Cicala, l'Antico Opificio Serico De Negri, Industrie Tessili Alois, the Manifattura Tessile Boccia, Alois, Passamanerie San Leucio, Arte Seta Alois and Giuseppe De Negri e Figli, to protect both the quality and originality of their silk products and promote them internationally. Less known are the cases of cities like Krefeld in Germany, also known as the German silk capital, especially in the 18th century when small family workshops became a powerful silk textile industry, or the case of Zurich, which, during the 19th century, had a strong silk industry. These local examples are proof of a complex history that intertwines through the centuries, that has shaped material, and that is scattered in important museum collections, but also in small factories that are still standing and often are unprotected without inventories and are therefore at risk of conservation. In the next section we will demonstrate how this heritage has survived and evolved in these three countries.

\subsection{The Living Heritage: From an Integral Heritage Perspective}

\subsubsection{Italy}

The tradition of rich silk fabrics in Italy survives thanks to the realities bound to the territory. In San Leucio, few echoes of the textile tradition that had made this territory a pearl of innovation of the silk heritage remain. A few companies resist to let the precious fabrics live on for an elite market. This is thanks to a heritage that enhances the ancient looms, but uses modern looms, re-proposing lampas and damasks with designs of the San Leucio tradition, such as Annamaria Alois, whose company also houses a small silk museum, with ancient looms and cardboard tables of the post-Bourbon era. Italy, recognized as the home of high fashion, has a settled tradition in the production of high-quality textiles, especially in the territories of the historic silk factories of Como, or Prato as well for wool and cotton. In these places, merchants organized the work at home in rural areas, such as the mountain plains and valleys of Lombardy and Veneto, or urban centres, even small ones, which were true proto-industrial spots such as Cremona, Monza, Milan, Bologna or the small town of Chieri in Piedmont where there are still ancient looms. Moreover, there is Zoagli on the Ligurian Riviera, where as early as the 16th century, a collaboration began with the Genoese silk weavers who supplied raw silk and bought precious fabrics to export so that Zoagli supported Genoa in the production of precious silks and velvets until the beginning of the 19th century, and still today is distinguished by a niche production made with the same 19th century looms. Italian industrialization took place mainly in the northern part of the country, which benefited from several very important commercial contracts already in ancient times, for example in the Mediterranean area and with Asia as prviously mentioned and the Silk Road that flowed into Venice. In modern times, thanks to contacts with Europe, industrialization was facilitated by the fact that it could count on a long manufacturing tradition, thanks mainly to the rich water resources and the propaedeutic cultivation of mulberry trees and silkworm breeding. Few companies still keep the tradition of silk and fine Italian fabrics alive today. 
It is impossible to make a complete excursus of the small and big companies still present, but there are some names historically rooted to the territory and must be mentioned, including Florence L'Antico setificio fiorentino, which still uses 18th century looms, as well as Luigi Bevilacqua in Venice, which also owns several Jacquard looms, as well as very old warping machines. Many companies have had to modernize their production to survive, but without losing the high quality and exclusiveness of the antique fabric. In the area of Como, the Mantero, founded in 1902, absorbed the historical brand Cugnasca, which today produces and distributes Emilio Pucci's ties and Clerici Tessuto, ranging from ready-to-wear clothing and men's accessories and furnishing fabrics. Ratti is a large industrial group that maintains the charm of the "made in Italy" label, which maintains synonymous with quality, even on the catwalk as well as in the cultural and artistic worlds. It is always based in Como, yet it is internationally recognized both in the field of fashion and in general as a standard-bearer in the cultural and artistic world. In 1996, Antonio Ratti donated a restoration laboratory for textiles to the Metropolitan Museum of New York, and today the Fondazione Ratti spreads the cultural heritage of the textile world thanks to the Museo Studio del Tessuto, whose collections have been considered to be of exceptional interest to the Italian State and subject to restrictions since 2007. Another well-known name in the silk production of fine fabrics is Taroni, which exports to 70 countries and, in addition to the clothing fabrics used by all the major international brands, produces flags such as those of the Vatican as well as sacred vestments and clothes for cardinals. The ecclesiastical field has always represented the breeding-ground for the maintenance of tradition, but has also been a hothouse for small new innovations. The historical heritage of Italian textiles remains alive thanks to small museums scattered throughout the Italian territory that recall how the history of textiles is intertwined with local history. What are also worth mentioning are the very small collections of ecclesiastical vestments, evidence of great ancient manufactures still kept in diocesan museums and in small parish collections, but above all to great realities such as the foundations that have preserved fabrics, drawings and the tools to transmit the knowledge of ancient manufactures. Among the most important Italian museums and collections, is the Palazzo Mucenigo Museum in Venice, with a significant collection of fabrics related to historical clothing; the Museo del Tessuto di Prato where the remarkable and varied collection also boasts a rich collection of sample books of the Prato area, in addition to the machinery that has characterized the history of textile production; the Poldi Pezzoli Museum in Milan, which in its heterogeneous collection and also boasts an important collection of ancient fabrics from the production of different civilizations some now extinct; and the Gandini Collection in the Museo Civico d' Arte of Modena which boasts more than two thousand five hundred textile fragments. Another distinguished example is the Fondazione Arte della Seta Lisio in Florence which still produces precious silk fabrics, and which does its best to train highly specialized weavers, using ancient Jacquard looms and transmitting textile manufactures that risk oblivion. Another prestigious Italian reality is the Rubelli Group, today based in Marghera. Born in Venice, it continued the activity of the Trapolin company, founded in 1835, which in 1858 had acquired the 18th century silk weaving mill of Giacomo Panciera. In 1889 the business was sold to Lorenzo Rubelli: this was the birth of the "Gio. Battista Trapolin successor Lorenzo Rubelli e C.", which immediately made a name for itself on the Italian textile scene for the extent of its eclectic iconographic repertoire, in line with the taste of the time. The Rubelli weaving mill still houses three perfectly functioning 18th century hand looms that were moved from Venice to Cucciago in the 1990s. The ancient handlooms still today allow the production of soprarizzi, which are precious handmade silk velvets. This is a process that very few companies in the world are still able to perform. A three-dimensional effect is obtained following the ancient technique of "chiselling", which involves the complex operation of cutting a part of the velvet surface with a blade.

\subsubsection{France}

In the departments that made up the former Rhône-Alpes region, there are now only about forty companies still active in the silk industry, employing about 1500 people. Their weight in the regional economy has therefore considerably diminished compared to what it was in the mid-19th century. 
However, all the stages of silk processing, from yarn production to fabric, are still represented: milling, weaving, printing on fabrics, dyeing and, more broadly, finishing and tailoring. These companies work mainly for the fashion industries and haute couture, but also for decorators or for historical monuments. Some of them have a long history. These are, for example, the societies Prelle of Tassinari and Chatel which, thanks to their long and complex genealogies dating back to the 18th and the end of the 17th century respectively, have textile archives of exceptional richness. However, the initiative and control are no longer really in the hands of silk merchants or manufacturers in Lyon or Saint-Etienne. Indeed, today's independent companies are small- or medium-sized and lack the financial base of the major 19th century merchants. Thus, Prelle of Tassinari and Chatel today employ only about thirty people and are located in a niche market. The regional family businesses, therefore, do not have the means to ensure on their own major investments to modernise their equipment and to develop their activity to a large extent. The silk industry is today dependent on the capital mobilized by major fashion groups which intend to maintain its coherence in France and perpetuate the know-how that is useful to them. This is particularly true of the Hermès Group, whose textile holding company is made up of companies acquired since the 1980s, the majority of which are located in the Lyon region. Hermès thus controls all activities from weaving to printing, dyeing and finishing. Its textile holding company includes Atelier de tissage de Bussières et Challes in Bussières (Loire), Ateliers d'enoblissement d'Irigny (Rhône), Ateliers A.S. in Pierre-Bénite (Rhône) specialising in flat-frame printing, particularly for scarfs, Gandit in Bourgoin-Jailleu (Isère) specialising in image and engraving work, the Société d'impression sur étoffes $d u$ Grand-Lemps (Isère) and the Société innovatrice de confection which, in Bourgoin-Jallieu (Isère), which brings together the Hermès clothing and prototyping workshops and where silk squares are cut and mounted in ties or rolled up. The holding company also controls Bucol in Pierre-Bénite (Rhône), which creates plain, patterned and printed fabrics for fashion houses, designers and high-end ready-to-wear fabrics. Since 1989, Hermès has also been a minority shareholder in Les tissages Perrin, France's leading silk weaving company, which processes most of the silk imported into France, and belongs to the Perrin et fils group, which also owns shares in a silk throwing mill in the Ardèche. In 2015, the Sfate et Combier group was taken over by Texunion-Bulteau, a holding established outside the Rhône-Alpes region. Positioned on the production of top-of-the-range silk, Sfate et Combier was created by the takeover of a former silk fabrics manufacturer (Combier) by a company once specialized in throwing. After 1992, it had strengthened the control of its production chain by acquiring a weaving mill in Isère (Doissin), a throwing mill in Ardèche (Prades) and other silk fabrics manufacturer in Lyon (Guigou) with a production plant in Saint-Rambert-d'Albon (Drôme). Currently, Guigou has reoriented its production towards jersey.

More recently, in 2016, the Chanel Group became a minority shareholder of the Denis et fils, a small or medium-sized company, of which it has been the largest customer since the end of the 1980s. This company, located in Montchal (Loire) was founded in 1956 and was initially a subcontractor, then it created top-of-the-range natural silk fabrics for its account. From the end of the 1990s, it embarked on a strategy of vertical integration by taking stakes in Hugo-soie ennoblissement, a dyeing and finishing company, and then in the Moulinage de Riotord (Haute-Loire), a company specialising in yarn preparation. Chanel's support enables this SME, which employed only about sixty people in 2018 and whose financial resources are limited, to consolidate its modernization and development strategy.

The legacy of silk activities in Lyon and Saint-Etienne has also left its mark on institutions representing economic interests. Thus, within the Chamber of Commerce of Lyon, created at the beginning of the 18th century and one of the most important in France after that in Paris, the activities linked to the trade and production of silks and silk fabrics exerted a preponderant influence until the middle of the 20th century. It was under its auspices that the Fabric Museum of Lyon was created. It was also at the request of the Lyon factory that the first "conseil des prud'hommes" in France was created in 1806, an institution designed to resolve individual and local industrial conflicts between employers and employees, which was later extended to the whole of France and all commercial or industrial activities. This institution was even adopted, sometimes with adaptations, in other countries. 
Moreover, as early as before the First World War, all the main silk working, and silk trading activities had a professional organisation defending their interests. Today, Unitex Auvergne-Rhône-Alpes is largely the heir to these organisations and, in collaboration with the Intersoie association, takes care of the interests of the silk industry. After years of difficulties, recent efforts to enhance the value of the silk fabrics have been made, notably with the launch of Silk in Lyon, an annual event that takes place over several days in November and is coordinated by Intersoie. It was born from the convergence of two types of previous initiatives: on the one hand, the silk market, launched in 2004 by Unitex and Intersoie, which aimed to promote Lyon's silk industry, and on the other hand, the Label soie festival, supported by the city of Lyon, which had a more cultural orientation. The 2019 edition was marked by the launch of the Silk Cities network, whose aim is to bring together a dozen international silk metropoles by 2025. Hanghzou (China), Tokyo (Japan), Londrina and Curitiba (Brazil), Valencia (Spain) and Como (Italy) are the first members.

The major economic and social role played by silk-related activities in south-eastern France is also manifested by the existence of a rich architectural, technical, cultural, tangible and intangible heritage that a network of institutions of varying status seeks to defend, preserve and enhance. Alongside older institutions dating back to the 19th century, in particular, there is a generation of museums born after the 1960s, in the context of a rapid decline in silk activities. In the former raw silk and yarn production areas, from the Ain in the north to the Gard in the south, one can still see along the watercourses many buildings of former mills, of which a systematic census and typological classification has been attempted for the Ardèche department. All the activities from silkworm breeding to weaving, printing, dyeing and finishing are the topic of museums. The museums located in the former regions of silkworm breeding or silk thread producing (the Gard, Ardèche or Drôme departments, in particular) rather deal with sericulture. In the Gard, several museums recently renovated, refurbished or reconfigured are intended to recall the major role played by sericulture and spinning in the rural economy of the Cévennes: the Maison rouge-musée des vallées cévenoles in Saint-Jean-du-Gard is located in the premises of a former spinning mill; and the silk museum in Saint-Hippolyte-du-Fort and the Cévennes museum in Le Vigan present silk-related activities from sericulture to weaving and knitting. Finally, the Cévennes National Park also contributes to the preservation and enhancement of the heritage linked to the production and processing of silk (La Roque silkworm nursery). In Ardèche, more modest structures recall that this department was the first in France for silk throwing at the beginning of the 20th century with the ecomuseum of the Chirols silk mill, the museum-magnanerie du moulinage de la Neuve in Marcols-les-eaux, that in Lagorce or the silk museum of the Château des Roures in Labastide-de-Virac. Silk activities are also evoked by the Arche des métiers, in Le Cheylard, as part of a presentation of recent textile innovations. In the Drôme, the silkworm's nursery in Saillans and the silk workshop-museum in Taulignan are also worth mentioning.

Silk fabrics and weaving are the main focus of the museums located in Lyon, in Saint-Etienne or in localities that once worked for the merchants of these two cities. The Musée des tissus de Lyon, after being threatened with closure, is currently the subject of an ambitious renovation project. Inspired by the South Kensington Museum in London and inaugurated in 1864 under the auspices of the Lyon Chamber of Commerce, it has one of the world's richest collections of silk fabrics, a very rich documentation centre and a textile restoration workshop. For its part, the Musée d'art et d'industrie de Saint-Etienne has the largest collection of ribbons in the world, which is the subject of a special tour. In Lyon, other institutions either have associations such as Soierie vivante, which ensures the preservation and animation of two weaving workshops owned by the city of Lyon or have privately managed structures, such as the Maison des canuts, which ensure the preservation and promotion of silk weaving techniques, such as in the Croix-Rousse district, the emblematic district of Lyon's weaving industry from the first decades of the 19th century. The spread of silk weaving outside Lyon in the 19th century explains the presence of museums devoted to silk production in the departments bordering the Rhône. In the Isère, the Musée du tisserand dauphinois in La Bâtie-Montgascon, in the Loire, the Musée du tissage et de la soie in Bussières, the Musée de la soie in Charlieu and the Musée de la cravate et du textile in 
Panissières present weaving techniques on hand looms or mechanical looms and offer demonstrations to visitors. For its part, the Bourgoin-Jallieu museum offers a rich itinerary evoking, in addition to the weaving activities, the finishing operations (engraving, photo-engraving, printing and dyeing) of which Nord-Isère was an important centre. Finally, in the Ain, the Musée des Soieries Bonnet in Jujurieux is located in the premises of a former and important textile factory. Endowed with a rich collection that sheds light on nearly two centuries of activity of a factory founded by one of Lyon's most important silk manufacturers, this museum also illustrates a specific type of work organization: the "usines-couvents", where the working women (around 550 in 1867) were housed in the factory, generally supervised by nuns. Currently, the actors of the Auvergne-Rhône-Alpes region who work to defend or enhance the textile and fashion heritage are grouped within a network, bringing together structures of various statuses; the directory of these institutions can be browsed on an interactive $\operatorname{map}[48]$.

\subsubsection{Spain}

As stated, the 18th century should be considered the golden age of European silk, with Lyon as the leading centre for textile production and innovative designs. The Spanish monarchy authorized in 1750 the imitation of the Lyonnais production model, this facilitated innovation in the Valencian silk industry as shown in the case of Joaquín Manuel Fos, who introduced technical advancement in the moiré in 1777. However, the biggest initiative that was taken for this purpose was the creation of the Real Fábrica de Tejidos de Seda, Oro y Plata de Valencia, which was put under the direction of the Cinco Gremios Mayores de Madrid and hired numerous draftsmen and manufacturers of silk fabrics of Lyon, who in 1756 were granted numerous privileges that placed them at the head of the Valencian silk industry [54]. For this reason, they settled in Valencia at the initiative of the Royal House, the Lioness cartoonists René Marie Lamy, Jean Joseph Georget and Pierre Sauvan, and the master manufacturer of silk, gold and silver stoles Jean Baptiste Felipot, to train the Valencian weavers and designers. The Royal Silk Factory of Valencia had a very special structure inspired in part by the one known as Grande Fabrique de Lyon, as the so-called "Main Factory House" coexists, in whose building was exhibited the royal coat of arms and the old union organization of the ancestral Gremi de Velluters. Therefore, due to low supervision of the main factory, independent manufactures run by weavers grouped in the Colegio del Arte Mayor de la Seda de Valencia would have had the possibility to roll or to mark to lead its fabrics with arms of the king and with the denomination of royal factory. The constitution within the Real Academia de Bellas Artes de San Carlos de Valencia of Estudios de flores y ornatos was an innovative initiative in the field of applied arts and more specifically in the textile and silk sector. Carlos III definitively established the Escuela de flores $y$ ornatos applied to the Fabrics in 1784 through the Royal Order and shows the dissemination of the Lyon model as the main silk centre [55]. However, the Academy's most important legacy was the system itself, which was inherited by silk industries. They began to proliferate in the early 19th century in Valencia and its surroundings, where some of them are still active today, such as Garín or Catalá. These companies, together with the introduction of Jacquard looms, deeply transformed the silk industry.

The Garín family have been silk weavers since the 18th century. The creation of their silk factory dates from 1820, when they made the transition from a guild workshop to a proto-industrial factory that later housed up to 40 Jacquard looms. Their fabrics show a vast repertoire of textile techniques, designs and motifs, from the simplest to the most complicated. Currently, the Garín family still exists. It is the seventh generation that weaves with Jacquard Looms. Their designs recover the nineteenth-century tradition. Weaving techniques such as damasks, espolines and brocatelles can be found in their collection. Their fabrics are so exquisite that they have dressed popes and kings. Nowadays, the industry is aligned with the traditional Fallas, but also has religious commissions, especially for religious imagery. On the other hand, nowadays there are other industries that come from artisanal weavers, but they had to reconvert to modern industries, such as Camilo Miralles, Vives y Marin, who use mechanical looms but their designs are still inspired in historical patterns, conserving a part of this heritage. There are also 
larger industries that are fully dedicated to the production of mechanical silk fabrics, such as case of Sedica, for example. The fact that Valencia has a strong identity related to the Fallas, the World Intangible Cultural Heritage, has made some other professions such as attire weavers or designers arise, and more importantly, they preserve this important heritage.

Many of these collections remain in small and medium museums that preserve this historical heritage, which includes fabrics, drawings, tools and machinery. For example, the Insa collection [56], which is an important costume collection with many pieces produced by the company. Insa was an important company dedicated to clothing design, including theatre, festivities and regional dresses. It also includes paper designs, photographs, commission books and textile samples. This collection is now held in the Museu Valencià d'Etnologia and the Museu de la Festa, both in Spain in the Valencian region. These types of collection are an important legacy for designers who can use them as inspiration models. Other museums that have this heritage are: Palacio Real, The Colegio del Arte Mayor de la Seda, Museu Valencià d'Etnologia, Museo Textil Ontinyent and many small parishes and ecclesiastical museums. Finally, there is a living example, Vicente Enguídanos also known as the last velluter, whose collection was donated to the Museu Tèxtil d'Ontinyent, the Museo de la Seda and the Museu Valencià d'Etnologia.

It is impossible to mention in this small excursus all the identities that guard the material and immaterial textile heritage of silk in Italy and keep it alive. In addition to the craft and industrial reality, there are many small museums and foundations scattered throughout Italy that aim to safeguard the local textile culture, since silk and its processing assume a constant and fruitful interaction between knowledge, technique and vocation of the territory in all phases of production, becoming a pivotal point of the indigenous history, forming its identity and influencing its development and culture.

\subsection{The Traditional Silk Industries and Their Cultural Heritage in the System of Design and Innovation}

Cultural heritage linked to handicrafts and traditional knowledge has a strong link to intangible heritage, but, at the same time, contemporary crafts have a close dialogue with creative industries [57]. Therefore, UNESCO recognized that "craft products are those produced by craftsmen, either entirely by hand, or with the help of hand tools or even mechanical means, provided that the direct manual contribution of the craftsman remains the most important component of the finished product. They are produced without limitation in terms of quantity and using raw materials from sustainable resources. The special nature of artisanal products is based on their distinctive characteristics, which can be utilitarian, aesthetic, artistic, creative, culturally linked, decorative, functional, traditional, symbolic and significant, religiously and socially". The 2003 UNESCO Convention especially recognized the value of the techniques and knowledge used in craft activities, rather than of the craft products themselves. The task of safeguarding should be directed primarily at encouraging artisans to continue manufacturing their products and passing on their knowledge and skills to others, particularly within their communities [58]. This will help cope with the competition of mass production, the homogenisation of festive and immaterial expressions and the disinterest of young people, both as consumers and also as potential heirs of such knowledge. In this sense, educational actions and the promotion of competent socio-occupational integration training can be an important stimulus. On many occasions, these artisan traditions contain "trade secrets" that should not be revealed to outsiders. Therefore, if family or community members are not interested in learning these traditions, they will not be able to appreciate, value and maintain their collective histories and the knowledge may disappear. One of the major concerns is to promote the learning of traditional knowledge among the youngest. This is a real challenge that faces not only up to the value of cultural heritage, but looks beyond its testimonial value and makes it an important asset in the knowledge society and as a generator of employment [59].

To this end, since 1995, UNESCO together with the Felissimo Group (Japan) has been promoting the Design 21 Programme [60], an international competition for artists and designers, able to use their art as a way of creating a new lifestyle and as an instrument to improve the quality of individual expression and communication with others and the Tribute 21 project whose aim is to create "DREAM centres" of arts activities for children in post-conflict countries. In order to promote the cultural and economic role 
of handicrafts in society, UNESCO promoted the UNESCO Award of Excellence for Handicrafts by promoting the development and maintenance of quality products, techniques and traditional motifs. A brand that, as a stimulus to innovation, creativity and the conservation of ancestral knowledge and crafts, has inspired others at the national level such as the Sello de Excelencia de Artesanias de Chile [61], and later the UNESCO Reconocimiento de Excelencia de la UNESCO para la Artesanía del Cono Sur: Argentina, Chile, Paraguay y Uruguay, which aims to encourage artisans and craftswomen to produce quality products originally using traditional techniques and themes to ensure the permanence and sustainable development of this activity in the contemporary world. At the European level, the Italian private initiative of the MMAM stands out (Maestro d'Arte e Mestiere (Milán) and the Libro dell'Eccellenza Artigiana Italiana, whose aim is to maintain and recognize the living treasures (Tesori viventi) and pay homage to the craftsmen of national creative and productive excellence, and as heirs of history and its cultural and human legacy [62]. In Spain, the Premios nacionales de artesanía de Españoles and the Premis d'artesania de la Comunitat valenciana stand out as concrete examples of a somewhat wider universe $[63,64]$.

In this area of cultural heritage, which is applied to tradition and craftsmanship, innovation and the application of new design-based formulas are becoming increasingly important. As we have seen, at the international level, the involvement of young people in these programmes is essential as a mechanism through which to preserve memory and ancestral knowledge and to foster respect and appreciation for the cultural heritage linked to identity, as an element of social cohesion and to foster future creativity from a perspective of sustainable community development [65].

\subsubsection{A Knowledge Management System for the Development of New Designs and Products}

The SILKNOW project is based on preserving the European silk heritage, making it accessible and approaching it as key driver of innovation in economic modernization from a sustainable point of view. With these premises, one of the objectives is to dynamize the creative research processes within design and to articulate a knowledge management system for the development of new products, helping at the same time to preserve cultural heritage. Knowledge management is one of the great paradigms of management in the forthcoming decades. SILKNOW has the vocation of being an instrument to position design within the European innovation system. In design, the repository of knowledge is not only the material culture and contents of museums but also the executive abilities of the maker and creator [66].

The process of this knowledge through tools such as product maps, comparative analysis, image recognition and interpretation, turns into a global and results-oriented knowledge management model. Most policies in developed countries integrate design into their product and service sectors (Denmark, Ireland, Finland, Korea, Sweden, Norway, New Zealand, England), and use design as a strategic tool for economic progress, improving competitiveness, developing businesses and creating new business opportunities. It is common to see design grouped with other economic sectors such as architecture, music industry, tourism, sports, industries and cultural institutions, all together in an area called Economy of Culture and Experiences. This is the result of merging arts and culture sectors within the corporate one. In a global economy, it is not enough to create technologically superior and lower-cost products, but also products and services of a higher quality that incorporate feelings, values, convictions, identity and aesthetics for which consumers are willing to pay more for, not only bringing more economic benefits to the industrial sector but contributing to the interests and prosperity of local communities. In this sense, highlighting the role of design in the preservation of identities and the dissemination of culture and knowledge will make end-users and consumers to identify products and brands with the culture of the area in which they were created. In this context, SILKNOW develops a spatial-temporal map where image recognition systems are essential for establishing product maps, as it analyses and explores records of historical-cultural heritage of European silk and generates creative and innovative proposals based on knowledge. 
3.3.2. Multi-Task Learning with Training Samples for the Image-Based Prediction of Variables Describing Silk Fabrics

This section gives an overview of how we use artificial intelligence for learning abstract knowledge about the images of silk fabrics, and how we can use this knowledge to support experts in cultural heritage and improve understanding of the European silk heritage. Knowledge about silk fabrics, e.g., about certain properties of such fabrics such as the production timespan or the production place, is often collected in databases (e.g., $[67,68]$ ) and can usually be accessed via the internet. Whereas such collections can offer information for up to tens of thousands of silk fabrics, the provided information is often very heterogeneous, as it is given as free text. This is rather problematic, because in order to develop and use digital tools for understanding cultural heritage, it is essential that annotations about the properties of fabrics are represented in a homogeneous, standardized way. Over the course of the SILKNOW project, cultural heritage experts have defined an ontology for the standardization of the information given in free text. However, mapping the text onto the ontology cannot be carried out manually, as reading the descriptive text and extracting the relevant information for tens or hundreds of thousands of images is tedious and expensive. Because of this, an automatic procedure for extracting the knowledge has to be developed. Such a procedure could be based on the automatic processing of available text. However, the textual descriptions may not contain certain pieces of information, either because they were unknown at the time of writing the textual description, or because the pieces of information were regarded as unimportant and, consequently, were omitted from the description. Another source for obtaining the required pieces of information about silk fabrics are the digital images of such fabrics. In recent years, research about image classification has been heavily influenced by the development of Deep Convolutional Neural Networks (CNN) [69], which has also found its way into the domain of cultural heritage and fabric classification. Most of the recent research addressed the classification of patterns shown in different kinds of fabrics. [70] investigated the image-based recognition of eight different types of structure in knitted fabrics and achieved overall accuracies of up to $98.4 \%$ using a $\mathrm{CNN}$. Other works focused on the recognition of patterns of woven fabrics, where a Residual Network architecture [71] achieved an up to $99.3 \%$ overall accuracy in distinguishing three different types of woven fabrics [72] and a 94.2\% overall accuracy was achieved by a MobileNet architecture [73] in classifying 10 different patterns of silk fabrics [74]. Whereas all these works investigated the derivation of one single characteristic of images of fabrics, Meng and others [75] proposed a multi-task neural network to simultaneously locate individual yarns in a fabric and determine a float-point location map. To improve the available knowledge about objects in a digital heritage collection, e.g., fabrics, one cannot only predict the properties that are directly related to the visual appearance of a fabric (e.g., the pattern of a fabric or fabric defects [76,77], but also more abstract ones). Li and others [78] assessed this task for cultural assets by means of hierarchically classifying first the type of asset, e.g., a painting, followed by a type specific classification, e.g., the artist of a painting. For that purpose, one $\mathrm{CNN}$ is trained per classification task; a first CNN determines the main type where, depending on its prediction, a type-specific CNN is used to predict a property of the identified asset type. To the best of our knowledge, there is no work that investigates the prediction of abstract properties from images of silk fabrics despite those developed in the frame of the SILKNOW project.

In the beginning of the SILKNOW project, we put our focus on predicting the production timespan of silk fabrics by using a $\mathrm{CNN}$ for image classification. At that time, only one collection of fabrics was available (i.e., only images of silk fabrics from Garin were used). Additionally, the provided annotations for the production timespan were not (yet) standardized; not only were the annotations for the production timespan given as periods of varying lengths (ranging from single days to centuries), but the various timespans had considerable overlaps. Both problems have been tackled by mapping the annotations to a hierarchical class structure, consisting of three half-century classes as well as two encompassing classes. The details about the methodology and experimental setup are reported in [79], the results of this approach are discussed in Section 4.2.1. 
After having shown that the prediction of semantic properties of silk fabrics by image classification is possible, we expanded the scope of considered properties to not only include the production timespan, but also the production technique and production place. The data we were working with at that time were around 10,000 images from [67]; each image came with annotations for the three semantic properties. However, around two thirds of the images came with what we call incomplete annotations, meaning that the annotations for one or two properties were unknown. In the first scenario, which we called single-task learning (STL), we trained one $\mathrm{CNN}$ to predict one single property, giving us a total of three CNNs. However, we formed the hypothesis that the prediction performance can be improved by, instead of predicting all properties independently from each other, training one CNN to predict all the properties at once. We assume that there are inherent interdependencies between the three properties, for example, that some production techniques were not used before a certain time. In this multi-task learning (MTL) scenario, the network is able to learn a joint feature representation for all three properties, while the class labels for the individual properties are predicted by property-specific classification branches of the network; this network architecture is shown in Figure 5. In this scenario, we assessed the impact of considering only complete training samples (MTL-C) as well as considering complete and incomplete samples (MTL-I). Our experiments, the details of which are presented in [80], have shown that the multi-task learning approach leads to a better classification performance compared to the single-task learning approach, but only when exclusively complete samples are used. The results of this approach are discussed in Section 4.2.1.

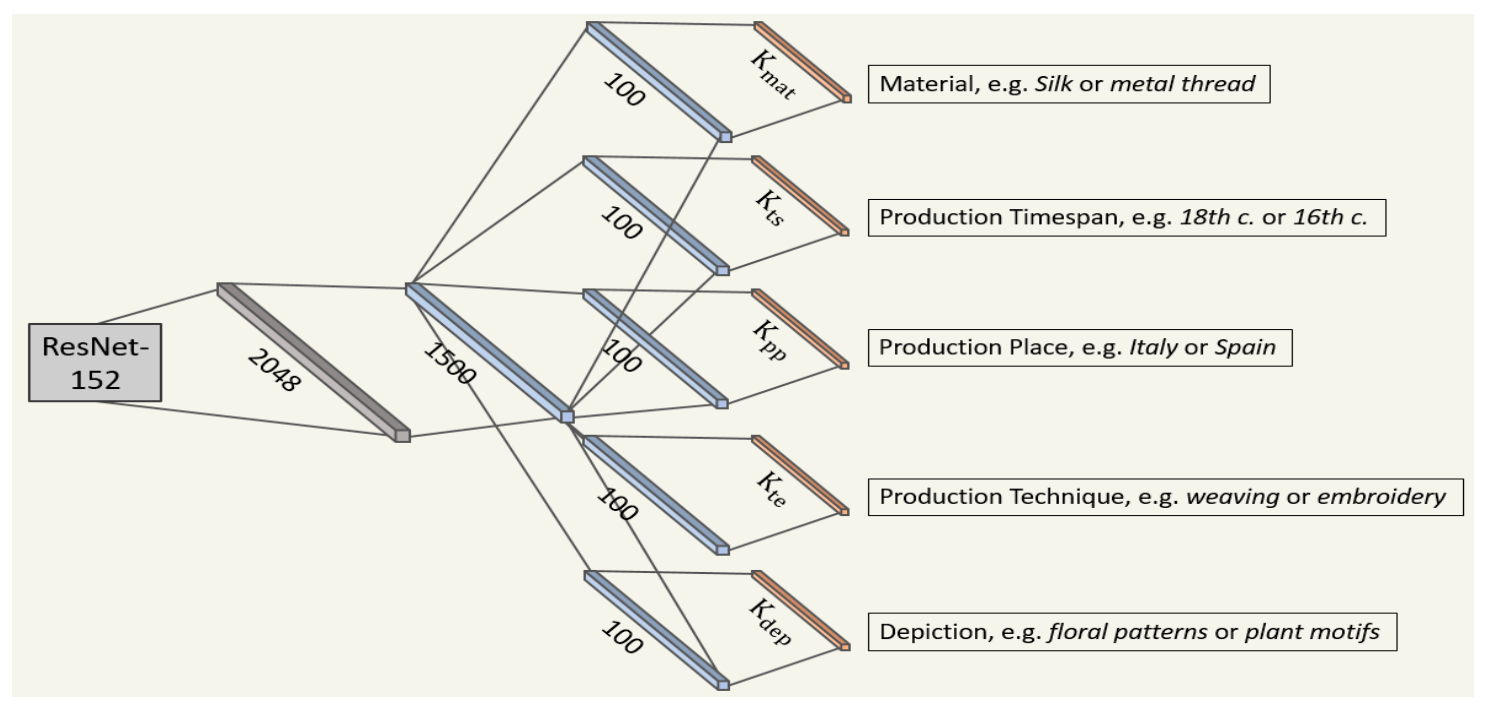

Figure 5. Network architecture for the multi-task learning approach. The network uses a pre-trained ResNet-152 [64] for the extraction of a generic, 2048-dimensional feature vector. These features are further refined into a 1500-dimensional feature vector, which form the joint feature representation. This joint representation is the basis for the five property-specific classification branches.

Recently, we have extended the scope of considered silk properties to not only include the production technique, production timespan and production place, but also the material and the subject depicted. Additionally, we are now working with images of silk fabrics from various museums and collections, giving us access to around 23,000 images along with annotations, although here we are facing the issue of incomplete samples to an even greater extent than before, as only 236 samples have complete annotations. In addition to the image classification via multi-task learning, we are also investigating the fusion of text and image classifications. Whereas the image classification takes an image of a silk fabric as its input, the text classification takes a free text as its input. Our hypothesis is that the classification performance of a joint classifier is better than that of two single classifiers. In order to test this hypothesis, we plan to train and evaluate a text classifier as well as an image classifier on the exact same set of samples. In this scenario, samples consist of (1) an image of a silk fabric, (2) a free text 
describing the fabric as well as (3) annotations for the semantic properties. After having trained both individual classifiers, we fuse them on a joint feature level, as shown in Figure 6. In summary, both the image classification as well as the joint image-text-classification can in principle be used to predict the unknown semantic properties of silk fabrics. Whereas the performance of the image classification has been evaluated in two simplified scenarios ((1) predicting only the production timespan with fabrics from a single collection and (2) predicting multiple properties with fabrics from a single collection), the joint classification remains to be evaluated.

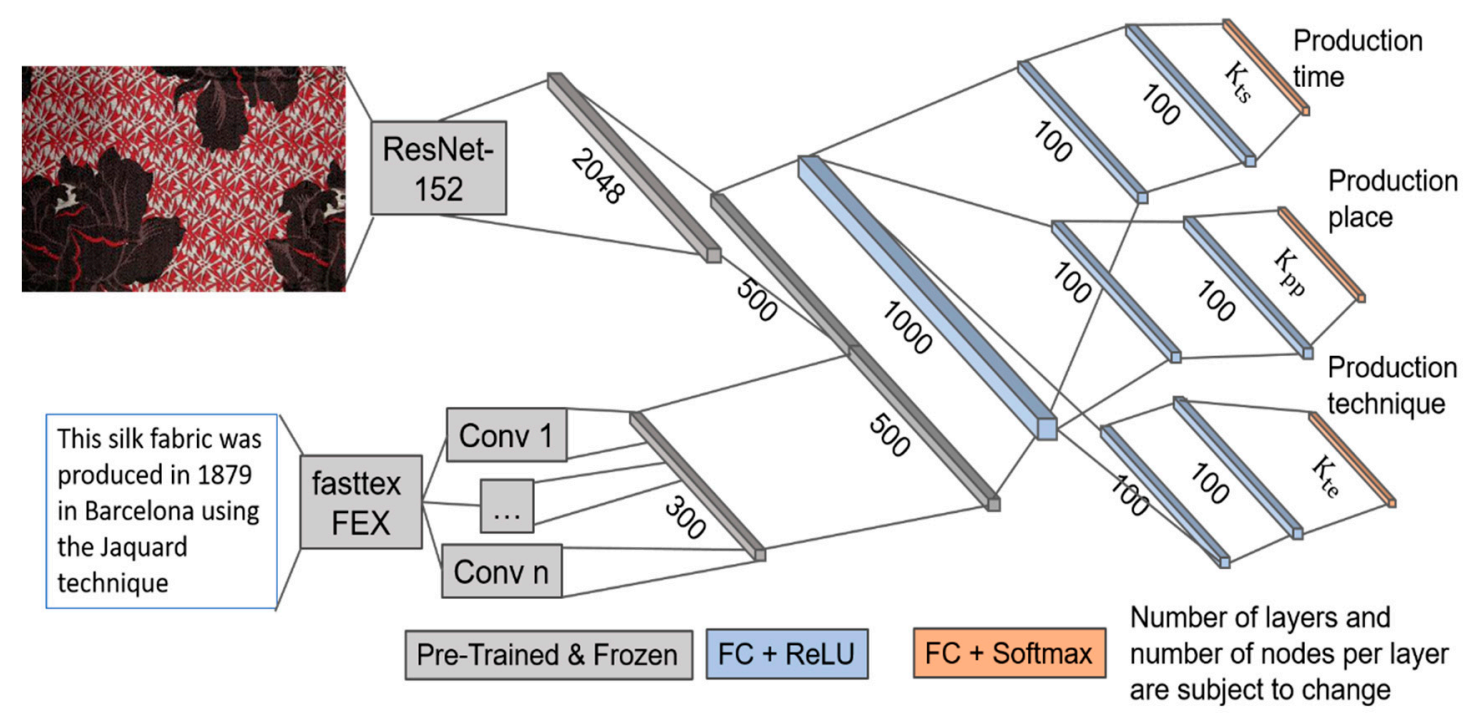

Figure 6. Concept for the network architecture for the feature-level fusion of image and text classification. The upper left part of the network represents the image feature extraction, which is based on a pre-trained ResNet-152 [64]. The lower left part of the network represents the text feature extraction. Both feature extractions give a 500-dimensional feature vector each, which are further refined into a joint 1000-dimensional feature vector. This joint feature representation is the basis for the property-specific classification branches.

\section{Discussion}

\subsection{Sustainability in the Preventive Conservation: Tools for Museums and Cultural Heritage Sites}

The analysis of the current project results makes it possible to identify two areas of key activities for the sustainable development of the communities involved. Firstly, the museum, through its capacity as a cultural heritage conservator, but also as a mediator and educational institution. From this perspective, the discussion focuses on the usability of tools in the processes of preventive conservation in museums, but especially in the educational field, on the promotion of universal and inclusive accessibility. Secondly, we propose to develop tools at the service of creative industries, from a double vision. On the one hand this helps promote the knowledge of a living cultural heritage and can thus develop social appreciation and interest in preserving it, while on the other it improves creative strategies for their development within sustainable economies. This is where the analysis is embodied within the design system and especially in tools linked to creative project processes, such as product maps, thanks to the generated image recognition system, not only in the professional field but especially involving design schools. We present the projects carried out between SILKNOW and EASD Valencia, a design school of recognized prestige.

\subsubsection{Accessibility for all at Museums and Heritage Sites}

Traditionally, silk had a major role as luxury fabric, whose products were the maximum of the material and cultural possibilities of many societies. This also makes silk objects especially abundant in many historical collections, not only for clothing but also as functional, symbolic, liturgical and furniture 
objects, etc. These collections, sometimes in large institutions of a national or global status, sometimes in small local entities, have been documented in many different ways over time. After decades of digitization, many museums have some kind of digital repository for their collections. In this respect, the diversity of situations is overwhelming: from a simple listing on a spreadsheet to a whole cloud-based collection management system. In the case of silk heritage, this information is already abundant in digital form but normally remains within the walls of institutions and within the reach of professionals and specialists only. The very minority nature of this heritage, mentioned above, is both a cause and a consequence of this situation. Old cataloguing records are of dubious authorship and authority with little or no standardization in their structure and terminology and are in accordance with very different methodologies in various languages. On the other hand, making silk heritage attractive to mass channels is complicated. It hardly falls into mass attention, such as authorship being associated with a famous name, a highly recognized location, or great public visibility. In this sense, one way of taking fabrics out to the public is to make them available through digital means. Accessibility in this sense will not only be for non-specialists, but also for people with vision or hearing difficulties and intellectual understanding.

SILKNOW is working with data coming from several museums that are not homogenized. On the one hand, collections vary in size and type of collection. We are working with huge databases (as shown in Table 1) such as the Victoria and Albert Museum (VAM) or the Metropolitan Art Museum (MET) and the Museos estatales (CERES) Spanish museums database, but we are also working with smaller collections such as OADI-Osservatorio per le Arti Decorativi in Italia. On the other hand, these collections are not homogenized, they correspond to different typologies such as Decoratif Art Museums (MAD, VAM, Rhode Island School of Design -RISD-) and the Fine Art Museum (MET), as well as textile museums (IMATEX - CDMT Terrassa-, GARIN). Finally, we are working with national databases (Joconde, CERES-MCU, UNIPA). We are working with a total of 38,380 records and 67,417 images. In the next table, there is a relation between museums and their records and images, for SILKNOW we only took those records that were useful for the project, which includes silk fabrics from the 15th to the 19th century.

Table 1. Data populating SILKNOW ontology.

\begin{tabular}{ccc}
\hline IMATEX (CDMT Terrassa) & 6802 records $(\times 3)$ & 9149 images \\
Joconde & 375 records & 384 images \\
MAD (Musée des Arts Décoratifs) & 736 records & 733 images \\
MET (Metropolitan Museum) & 8363 records & 13,790 images \\
MFA Boston (Museum of Fine Arts) & 6900 records & 7893 images \\
MTMAD (Musée des Tissus de Lyon) & 663 records & 2958 images \\
RISD (Rhode Island School of Design) & 3300 records & 4356 images \\
UNIPA & 29 records & 81 images \\
VAM (Victoria and Albert Museum) & 6808 records & 19,033 images \\
CERES-MCU (Museos estatales del MEC) & 1295 records & 2868 images \\
GARIN & 3109 records & 6556 images \\
\hline
\end{tabular}

Due to record heterogeneity, data quality varies according to the degree of specialization in each museum. For example, it is not the same when a collection corresponds to textile museums where conservators are highly specialized in several fabrics, designs and weaving techniques to when a collection corresponds to a small ecclesiastical museum (e.g., those coming from OADI). In this sense, quality also differs not only in the way of cataloguing (e.g., an absence of standardization in dates and techniques due to the lack of controlled vocabularies and different fields when writing a catalographic records, etc.) but also in the image quality.

Another challenge is the fact that not all the collections are open access collections. In this sense, data in their catalogues are the raw material, not only for a project like ours but for any serious digital development in heritage institutions. Although some large museums are leading the way (like the 
Metropolitan) by making large amounts of data about their collections freely available, in other cases, it is government agencies that are collecting information on some or many collections, such as CERES. In SILKNOW, working mainly with small and medium-sized museums, we are finding a whole range of possible situations: from the absolute lack of interest in sharing anything to an absolute data cession. Finally, the data harvested came in several formats from a simple Word file to an API. Data extraction was only possible thanks to an interdisciplinary team, in the next graphic we show the total amount of values of the two most important categories in SILKNOW (Figure 7): materials and techniques. Materials were selected because silk fabrics can be woven in several materials that were used in specific periods of history, to know this is essential when studying and cataloguing a fabric. Techniques, on the other hand, are essential to SILKNOW as we want to act as a digital memory for these historic techniques that nowadays only a few scholars and weavers know.

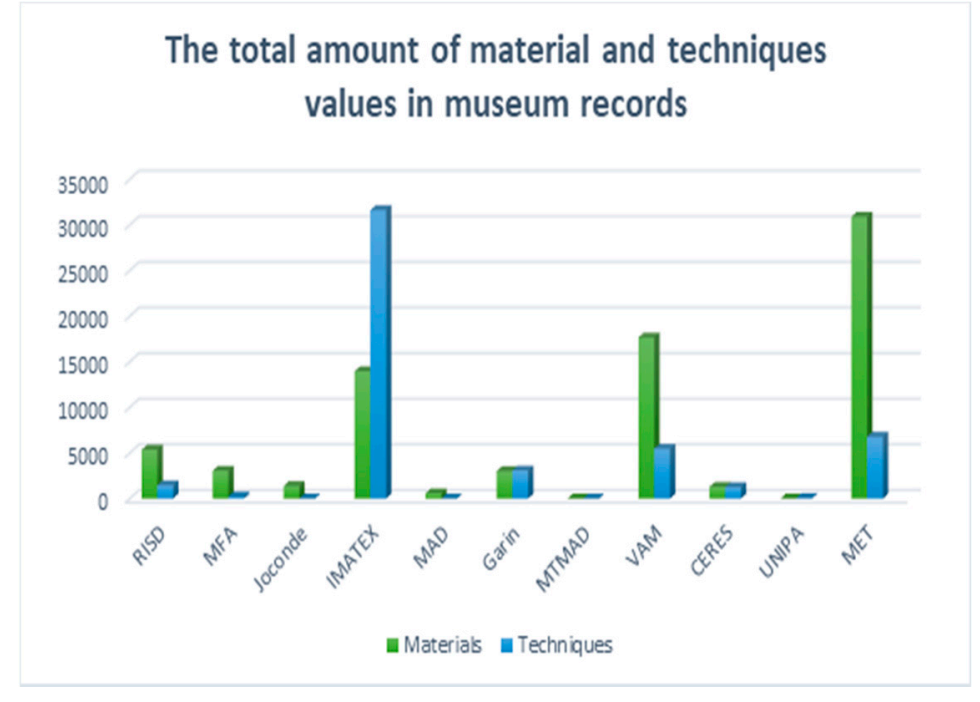

Figure 7. Values from SILKNOW records.

The SILKNOW project aims, among other things, to improve access to this heritage and associated digital information, through various tools. Following a policy of open access to the data we collect. It comes from various sources: mainly internal databases provided by museums and collections, with which we have agreements; and data already in the open, collected through APIs or websites. The result, still under construction, will be a repository where information from many sources will be brought together and made available to users through improved tools: multilingual interface and interrogation, thanks to a specialized thesaurus, organizing information through a data model specific to this type of heritage, based on CIDOC-CRM. SILKNOW also created a Virtual Loom that acts as a digital memory of historical weaving techniques and a spatio-temporal map where these collections will be shown. To sum up, SILKNOW offers a wide range of tools that provide accessibility to silk heritage collections.

\subsubsection{Education and Cultural Mediation}

The conservation of cultural heritage and especially the appreciation of its creative qualities forges an interrelationship between society and cultural heritage. It is capable of intervening in the cognitive articulation in the process of contemplation by using cultural objects as mediators. But it is also capable of intervening in the process of constructing new meanings or appreciating new values that commute or replace the previous ones. However, although cognitive, contemplative and educational values are essential, we cannot separate them from development activities, nor isolate them from emerging social changes, or alienate them from the concerns of communities [1]. Nowadays, ICT technologies permit users to be connected at all times and to the construction of spaces that can be transformed through 
using technologies [81]. Cultural mediation can rely on the use of ICT to support communication between their collections and audiences. In this regard, technology can be used to transmit knowledge but also to attract different categories of the public to museums [82].

SILKNOW contributes to a bigger understanding of Europe by improving the knowledge and preservation of European silk heritage through technology, since the de-territorializing of the traditional museum has allowed it to receive different audiences [83] and found new ways of bringing art and cultural goods closer to the public. The museum must be, in addition to a conservator, a procedural means of achieving the development of the community through cultural heritage [84].

Virtual Loom can allow museums to show the society how fabrics were woven without touching it, moreover, its capacity, to print them in 3D can help children and people with special abilities to touch them and even "play" with them. The spatiotemporal map can be shown at the beginning or at the end of a room displaying the relations of the fabrics exhibited in those rooms with others across Europe, hence explaining the importance of silk heritage in constructing European identity and commercial networks.

4.1.3. Interpretive Model in the Project Culture: Textiles as an Innovation Agent Applied to Creative Industries

Maintaining and preserving museums with their original industrial structures means preserving both a tangible and intangible heritage associated with them. Special attention must be taken to the dissemination of this heritage to preserve and maintain the artisanal tradition. In this sense, it is essential to combine tradition and innovation to guarantee the sustainability of this kind of heritage. Creative industries, including factories, are coming together to develop new creative structures that can merge into the conservation of silk heritage.

Several routes can be taken to conserve this heritage at the time of creativity and design spark. Museums can act as innovation and training laboratories, such as the case of the Textiel Museum [85] in The Netherlands. On one hand, the machinery is still working and is shown to the public, while their collection is used as a reference for contemporary designers. They own a TextielLab that works as an extension of the museum, where historical and modern techniques are applied by top designers, who can talk with the museum curators and use their knowledge as a source of inspiration from the production process to development. This example can be followed by other museums that can act as innovation laboratories but also can train younger generations of weavers that will maintain this intangible and fragile heritage. Such is the case of the Fondazione Arte della Seta Lisio Firenze [86], which promotes the art of weaving by teaching younger generations these historical techniques by using historical machinery. They also offer capacity building to professionals in the silk textile field; hence, they offer conservators, curators and university students' theory and practice, providing an indispensable knowledge to preserve silk heritage. Finally, this foundation weaves exclusive fabrics woven by master's weavers that are sold to haut-couture designers, palaces, opera and even movies. On the other hand, few existing companies are still weaving as they did centuries ago. These are essential to conserving tangible silk heritage (drawings, patterns, looms, fabrics) but especially intangible heritage (weaving techniques). GARIN 1820 S.A. [87] is a Valencian industry whose origins can be traced to the end of the 18th century when the family began to weave. They established their industry in Valencia in the early 19th century, becoming one of the most important European weavers, whose fabrics were used by royal families and even popes. Luigi Bevilacqua [88] is a Venetian company that can be traced to 1499 , however the actual workshop dates from 1875 when they recovered Venetian art, combining historical designs and techniques. Throughout its history, the company has been producing countless fabrics for renowned customers and famous buildings, including Stockholm's City Hall and the Kremlin. These types of industries are heritage themselves, as long as their activity lasts, cultural heritage is being preserved. They are the transmitters of intangible heritage and knowledge of historical textile techniques. They also contribute to their designs and historic collections that are spread throughout the world and are conserved in great museums and palaces. 
Artisans can contribute with their knowledge, by documenting, transmitting and preserving traditional techniques, which later on can be used for the proper use of materials and techniques in the conservation of these objects [65]. At the same time, the promotion of traditional industries and factories can benefit from the reuse of motifs, so that they bring these historical designs to the present, without forgetting the maintenance of a tradition in the ways of weaving, preserving the intangible heritage. In this sense, heritage institutions should create synergies with creative industries, including artists. Many artists work on textiles, specifically on silk, and use traditional techniques or historical designs to create. In this sense, their research begins with the tradition of innovation. Often, the objective of these artists is the preservation of traditional techniques and the promotion of textile culture through heritage, training and creation [89].

The international fashion world, which was already suffering, was overwhelmed by the crisis caused by the Covid-19 pandemic. This made the need for a more sustainable vision of productivity from raw materials to finished garments and made the resilience of the Italian textile industry a more pressing issue. Despite eco-sustainable ideals that many brands are taking on, unfortunately, fast fashion has caused several problems that are difficult to overcome. The term fast fashion, in fact, describes a fashion made of clothing and accessories produced quickly and cheaply, which corresponds to equally rapid and unsustainable disposal. It is a fashion of low quality, linked to seasonal trends, which aims at low costs and sales prices and exploits workers with poor wages and poor working conditions. From ethical problems to ecological problems and then to economic problems is a short step. In fact, this system also causes an overproduction called deadstock, where there are large quantities of unsold fabrics and garments. The most innovative sectors of the Italian industry are investing more and more in research in order to be eco-sustainable and competitive. One of the solutions that is being taken up more and more in the field is the adoption of upcycling. This system consists of the reuse and improved conversion of discarded textile products or even wasted raw materials [90]. Unlike recycling, upcycling does not reduce the value of the old and the waste but gives a new life to it. Today the challenge for designers is to use, reinterpret and make these fabrics attractive to the market. Among the best-known names who are exploiting the potential of upcycling are Cristopher Raeburn, Rafael Kouto and the AVAVAV brand [91]. In any case, silk, for its intrinsic qualities, including its strength and preciousness, remains one of the most desirable fibers, so it still becomes a protagonist of the contemporary world of sustainable weaving thanks to a historic Italian factory like MANTERO, which is now in its fourth generation. The company has been investing in research for years in order to find increasingly sustainable, cutting-edge production methods that fully satisfy the luxury world of international fashion [92]. This has led to the development of a series of projects under the name of RESPECT, aimed at promoting social and environmental sustainability and the circular economy. Among these, the one called RESILK is at the cutting edge and is already planned from 2015 [93], as an innovative fabric created through a process of silk regeneration, obtained from existing garments such as deadstock [94]. A traceable process certified Grs (Global recycled standard) in partnership with ECOTEC of Marchi and Fildi [95]. The revolutionary idea, the result of the company's research department, includes several processing steps to select the fabrics that are disassembled to be spun and woven again to become a new product. This involves endless solutions, such as working the silk with other precious fibers like wool, and creating original and precious products thanks to an always different mix [95]. The RESILK collection will be on the catwalks as soon as possible [96], embodying the new idea of post-Covid19 fashion, a symbol of resilience that does not renounce beauty, tradition and quality of materials, but with a new awareness, preserving the environment and focusing on sustainable production.

In this sense, one of the objectives of the SILKNOW project is to generate a direct effect on the creative industries both for the tools that will be generated and for their strategies to approach those audiences. Textile companies, fashion designers, 3D printing companies or the tourism industry are some of the sectors that are represented in the project either as partners or as collaborating institutions, thus guaranteeing the social use of the tools of this project. SILKNOW will promote 3D research 
applied to the textile world. On the one hand, piloting these printing techniques aims to pave the way for $\mathrm{R}+\mathrm{D}+\mathrm{i}$ and improve the incipient market of $3 \mathrm{D}$ printing on textiles. On the other, the knowledge and appreciation of historical fabrics gives the creative industries the possibility to offer their customers new and different products and, therefore, has the potential to create a new market niche, not only for specialized stores but also for large retailers, involving not only the field of fashion but also home textiles, decoration, furniture and design in general. Similarly, traditional silk mills, like many others, will be able to use historic designs as a source of inspiration and innovation applied to new products or even as new business models. In this way, SILKNOW seeks all these publics to be correlated among themselves so that European silk heritage can be disseminated, preserved and exploited at all levels, understanding silk heritage as an integral heritage in which several sectors are involved, since cultural heritage is not isolated from the society to which it belongs.

\section{SILKNOW as a Process and Management Facilitator in the Current Design}

An interpretative model specifies the adoption of a defining model of design management, as it reduces distances and "unites" project-related approaches and business management approaches. The model responds precisely to this objective: to create a connection within a unit framework capable of combining project and management areas under a single interpretative key. A second reason related to the use of an interpretative model is to draw the boundaries and attributions of design management. The model is useful for defining the areas in which design management acts as a regulator. A third and final reason is to consider the usefulness of the interpretative model linked to an orderly and inclusive systematization of logics and tools that refer to the areas of the project and management as a kind of open platform for future studies and contributions. In this process, our project is committed to produce a deductive model related to cultural heritage and applied to design. This makes it possible not to offer closed and false solutions, but to generate new models based on interpretation. The development of interpretive projects allows to promote design processes in an integral way within the innovation processes and interpret them within the design management system based on local culture and heritage as a sign of identity.

\subsection{Sustainability in Today's Industries from the Cultural Heritage Base}

The "cultural turn" [97] evidences the weight that culture has always had in economic and social development. Urban development policies have incorporated, as one of their most relevant strategies, the creation of the necessary conditions for attracting creativity and innovation, in line with Florida's [98] concept of the creative class. Some of the most used concepts are "creative city" [99] and "intelligent city" [100]. However, these strategies, which seek to generate the attraction of capital and talent to cities, have been criticized both for their questionable effectiveness as a trigger for innovative processes [101], and for their impact on certain areas which can lead to gentrification processes with negative consequences for residents and the more traditional local economy [102,103]. However, this cannot invalidate the opportunities that culture and heritage provide for development. Therefore, more than ever, it is necessary to link the concept of cultural industry with that of sustainability. The implementation of strategies that promote inclusion and co-creation, relying on social actors representing civil society, leads to sustainable and integrated development that benefits society as a whole. This implies an increase in the capacities and social capital of local communities, which, supported by education and cohesion, are capable of mobilizing citizens to make them participants in their sustainable development. This is a development that will be balanced, both from a social and economic point of view, without forgetting respect and care for the environment as the basis for quality of life. Culturally based companies can and must participate in this process.

\subsubsection{Digital Tools and Their Application to Design}

The tools developed by SILKNOW are fully integrated into the development of the culture of the design project as an interpretive model. Among its potentialities stands out its capacity to 
interpret silk heritage through the digital tools created for it. It has the ability to offer a resource based on interpretive models capable of "explaining" the dynamics and relationships that exist between different historical and cultural variables. This a-paradigmatic nature is directly related to what is often identified as the ultimate goal of the project's activities: innovation. Through its tools, specifically thanks to image recognition, based on open repertoires of silk museums, the project facilitates the formulation of queries, promotes communication by creating a common language between several actors in the project (from various origins) and enhances knowledge-based creation. From SILKNOW, innovation is understood as a process that combines forms of intelligence to create new knowledge. Projects and research to be carried out use knowledge as input, and transformation as output. The tools are proposed as a structural foundation, development and exploitation of its funds and may cover one or more of the following characteristics: from the outset, by activating a mechanism that generates new knowledge; transformers, because they systematize and organize different fragments of knowledge producing new ones; output, because they have the particularity of identifying factors of a transmissible "product/service".

The image recognition system is intended to function as a perceptual product map. The project works from the interpretative model and understands the product map as a development between analysis and conceptualization. It is a tool that represents and identifies concepts through files' digital treatment and their interoperability in a semantic web based on a knowledge graph. Product Map analysis is also formalized as a conceptualization process, it is not aligned by restrictions, and can detect/systematize a series of useful impulses for the development of a new product/service. The user can have visual elements where you can evaluate the state of a concept, product or project/final object. Product mapping is an agile dashboard, which allows, in a simple way, to locate the products in a space of related clusters by characteristics and capabilities. The analysis and conceptualization through Product Maps allow to collect useful information for the development and management of creativity and innovation in current design projects. From a strategic point of view, the analysis using product maps aims to define some possible innovation scenarios through knowledge-based interpretation of the heritage of silk. From the visual point of view, it allows us to identify key factors derived mainly from formal references, materials, techniques, chromatics or aesthetics. The definition of aesthetic profiles seems to be of extreme importance, especially in those sectors where the dynamics and logic of buying and adopting products are mainly guided by symbolic, perceptive and inspiring dimensions, linked to the form and "languages" of the textiles products. On the other hand, it presents a utility that is mainly related to the sectors dominated by functional and technological purchasing logic. The image recognition system for product mapping provides an analysis and exploration that collects and organizes materials and information through the visualization of maps, matrices and iconographic repertoires. Moreover, the dispersion of boundaries between sectors (for example, the textile sector going beyond the fashion supply chain to also reach the lighting, furniture and habitat products sectors) is combined with cross-fertilization processes, which hybridize technologies and production practices between different sectors, highlighting the increasingly strong relationship between different product areas concerning formal solutions, colors, finishes and materials that tend to move more and more quickly from one product to another.

\subsubsection{Digital Image Recognition: From Cultural Heritage to Product Map for Today's Designers}

As mentioned, one of the innovative functions that this image recognition tool will include in the project is the possibility of studying the evolution over time of historical silk models, as well as information support to be able to save and retrieve the data used to generate the product map.

In this part, we will discuss the multi-task classification performance of the image classifier presented in Section 3.3.2. In our research from [80], we mainly considered three different scenarios, namely single-task learning (STL), multi-task learning with complete samples (MTL-C) and multi-task learning with complete and incomplete samples (MTL-I). The three tasks, i.e., semantic properties, that were considered are production place, production timespan and production technique. The experiments were 
evaluated based on the overall accuracy achieved both for each task separately and on average across all tasks. The overall accuracy measures the percentage of correct predictions of the classifier, with values ranging from $0 \%$ to $100 \%$; the higher the value, the better the overall classification performance. The overall accuracies for the three scenarios for each property and the average overall accuracies are presented in Table 2. The table shows that MTL-C has the best classification performance for the three properties. On the one hand, this indicates that learning to predict all properties at once (i.e., multi-task learning) is beneficial over learning to predict the variables separately (i.e., single-task learning). On the other hand, the results show that this is only true if exclusively complete samples are used. When incomplete samples are used as well (MTL-I), the classification performance is on average worse than the STL scenario. One possible explanation is that the joint feature representation is dominated by incomplete samples, because the number of complete samples is relatively low. Thus, the joint layer learns a lot from samples that do not reflect the interdependencies between the tasks, which results in learned features that do not generalize well over all possible samples.

Table 2. Overall accuracies for the three scenarios from [80].

\begin{tabular}{cccc}
\hline Task/Property & STL & MTL-C & MTL-I \\
\hline production timespan & 85.8 & 92.3 & 85.4 \\
production place & 87.2 & 95.4 & 86.0 \\
production technique & 90.9 & 92.9 & 91.3 \\
Average & 88.0 & 93.5 & 87.6 \\
\hline
\end{tabular}

The evaluation for the most recent version of the image classification remains to be carried out. As explained in Section 3.3.2, we are now dealing with an expanded set of semantic properties as well as with images from various collections. Preliminary experiments show that overall accuracies of $60-88 \%$ can be achieved, which is considerably worse than the results achieved in [80]. A possible explanation for this is the expanded set of properties, which also leads to a more complex class structure for each property. For example, earlier we only considered three classes for the production timespan, whereas now seven classes are differentiated. As the class structures becomes more complex, the classification, of course, becomes more difficult.

The automatic image classification tool can support the specialists involved in innovation actions in carrying out their analyses; the group of designers will convey to their clients better-argued and detailed visions and analyses when it comes to encouraging innovation; the teaching communities will have the possibility with the use of these tools to generate a contrasted vision in the development of the teaching of projects and will be useful to the young entrepreneurs, be assisted with instrumentation that will allow them to broaden their vision of their knowledge-based business model and foster appreciation of local culture and their visual identity based on their knowledge of cultural heritage.

\subsection{Silk Heritage in the Knowledge Society: Design Learning}

From this perspective, we understand cultural spaces as institutions based on the transmission of knowledge, whose priority is to make culture accessible to each society, as centers of exchange and as open spaces for intergenerational and intercultural dialogue, where digital culture can foster these experiences. In this paradigm shift, the evaluation of the user experience is becoming increasingly important. Improving the understanding of cultural sites and museum collections via the web, but also of mobile applications, requires a complex but necessary task: the evaluation of digital applications and their reception by users. Monitoring knowledge acquisition is a crucial tool for proposing relevant recommendations for the design of digital experiences for cultural, educational and recreational purposes, as well as accessibility to information for society in general and for groups at risk of exclusion in particular. The interaction between ICT and cultural and knowledge resources facilitates the collection and unified dissemination of large volumes of information, beyond the walls of each institution. Increasingly common open data policies allow the transformation of resources designed 
for specialists, opening them up to much wider audiences. Today, large cultural institutions are betting on such projects based on big data analysis and artificial intelligence. An international example is the ambitious Arches project of the Getty Institute; the Finnish project Culturesampo which offers a web portal 2.0 and a Finnish cultural heritage publishing channel; World Monuments Fund (WMF) designed to be used independently by any institution in the field of heritage conservation, and allowing the creation of digital inventories through open source, adaptable and reusable environments by the scientific community, conservatives, wealth managers or Europeana.

SILKNOW's tools make it possible to map the knowledge that has been preserved in museums and open it up to society. It follows the line of other digital culture projects at the service of society, such as the Timeline Project [104] developed by the Prado Museum: an online tool that aims to develop the visualization of the museum's works in a timeline, placing them in their historical context, linking the works of art in their collection with the great historical, scientific and cultural events of their time, thus becoming an instrument of dissemination. In fact, the spirit of SILKNOW is to help disseminate and exemplify a policy of open access to data, as Europeana itself does; in this case, in the field of culture and knowledge.

In this sense, one of the most interesting projects, one with which SILKNOW maintains a close collaboration, is Silkmemory [105], a Swiss project that depends on the University of Lucerne. In its web repository it gathers the textile models of Swiss silk, donated by historical companies. Its visual mapping model introduces aspects of visual information such as color, iconography and technique and other concepts such as company, function, production or location. Along with educational design programs, its concept around Design and Arts incorporates different coordinates applied to creativity and innovation: design and history: ability to assess and research in the archives of industries and enterprises and their historical contribution to industrial and cultural development; design and materiality: associated with product design, it can serve as a development engine for new products, through experimentation with organic and non-polluting products, such as natural fibers or new applications with high development potential; design and technology: based on a creative vision, the application of new technologies can help strengthen industrial development, aesthetic applications, strengthening of materials and their durability and sustainability. Together with the development of high-strength materials or products, the development of new 3D technologies, and Design and Sustainability: the competences developed by research and the interdisciplinary approach can generate concrete applications in the field of design, industry and technology, from the point of view of the use of sustainable materials, research and the development of innovative processes in product research and market development.

\section{Experiences Applied in Design Schools}

The SILKNOW project tools have been tested collaboratively with EASD [106] Valencia (Figure 8). Specifically, its artificial intelligence-based tool for recognizing similar images and offering a repository based on a conceptual map or knowledge graph has been used as a tool for creative projects at this school design. Together with José Marín of the EASD Valencia, we applied the results of the SILKNOW project to applied design teaching. In order to do so, we chose fashion projects, where students could explore SILKNOW tools and apply them to a fashion project. We also selected students from the 2nd grade of jewelry, where students developed jewelry models, eight brooches, taking as a motif the historic designs of silk. This last project under the name "Like Silk" took several substantial steps. First a team of researchers from the Universitat de València went to the classrooms and held several workshops to explain silk history, textile heritage, weaving techniques and manufacturing processes. Then, students were able to work with the image records and SILKNOW. Later on, they choose their models and establish conceptual maps for the elaboration of their projects. 


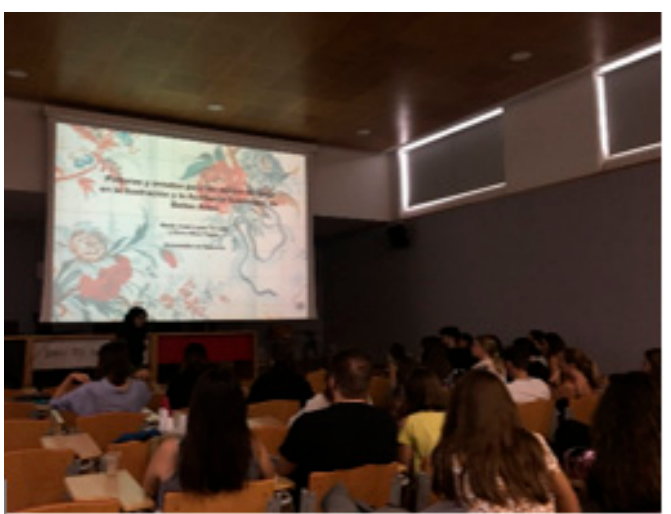

(a)

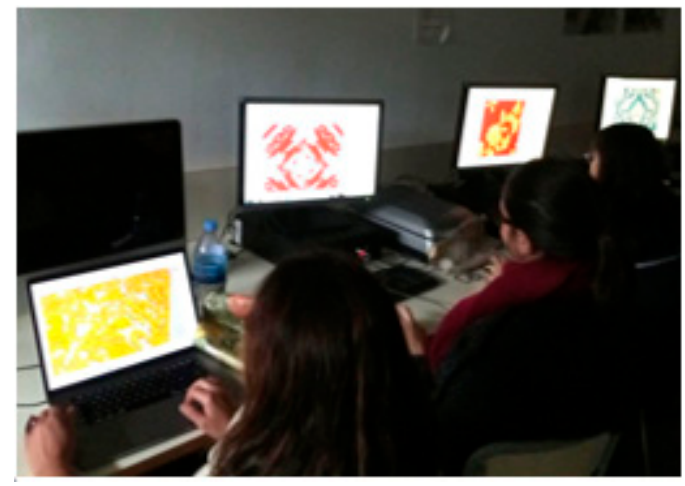

(c)

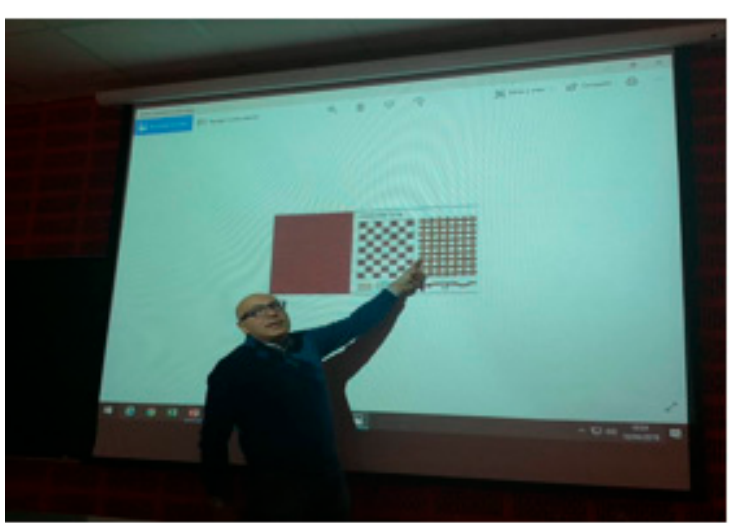

(b)

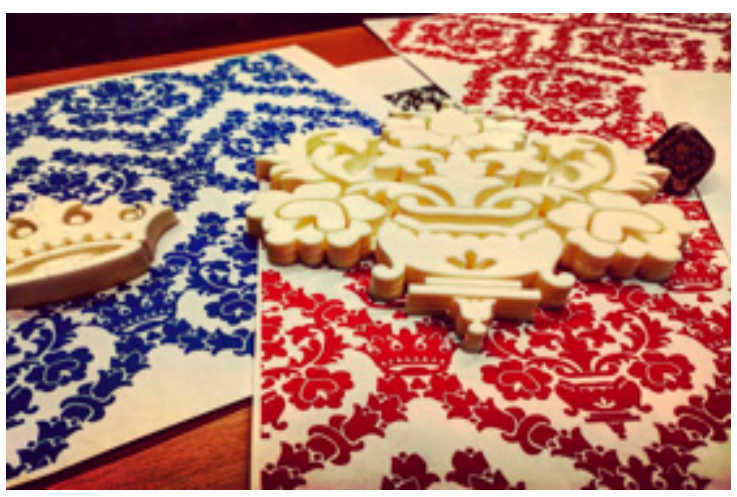

(d)

Figure 8. (a) EASD Workshop with fashion and jewelry students. (b) Prof. Maurizio Vitella teaching in València historical weaving techniques. (c) EASD jewelry students rendering silk images. (d) 3D printings based on Garin's records.

The pedagogical motivation is to bring an artistic vision to SILKNOW under the concepts of merging tradition and technology. They work with the idea of giving volume to flat prints and stretching them into a third dimension. The brooches (Figure 9) consist of a prototype structure in 3D in black PLA plastic. On this structure, a silk fabric was adapted and on the top as a motif of attachment, a metal piece was engraved with the name of the collection "Like Silk". Several experimental prototypes were made and finally it was decided that the 2nd grade jewelry and object students created a series of eight brooches. The methodology consisted of eight phases: 1. selection of eight silk fabric prints digitized; 2 . motifs vectorization, to this end the silhouette of the motifs has been drawn using the Rhinoceros program in its 2D version; 3. brooch design, study the prints and from them extract a silhouette that fits our technical and aesthetic needs; 4. 3D modulization of the structure that will hold the fabric and the base that will have the system clasp attached; 5. 3D prototyping of all brooch components by the MonkeyFab, a 3D printing company and a SILKNOW partner; 6. making a circular metal part that serves to fix the fabric to the structure; 7 . once the plastic parts have been prototyped, the parts are adjusted, the burrs removed and the stainless steel pin created. Finally, the fabrics are adapted to the structures, the metal part is fixed and the back parts with the clasp are mounted. The openwork technique of the structure of the pieces was inspired by a design of historic silk, as well as the shape of the object imitating one of its classic motifs: a vegetable leaf, a flower, etc. This structure was covered with a GARÍN's silk fabric. 

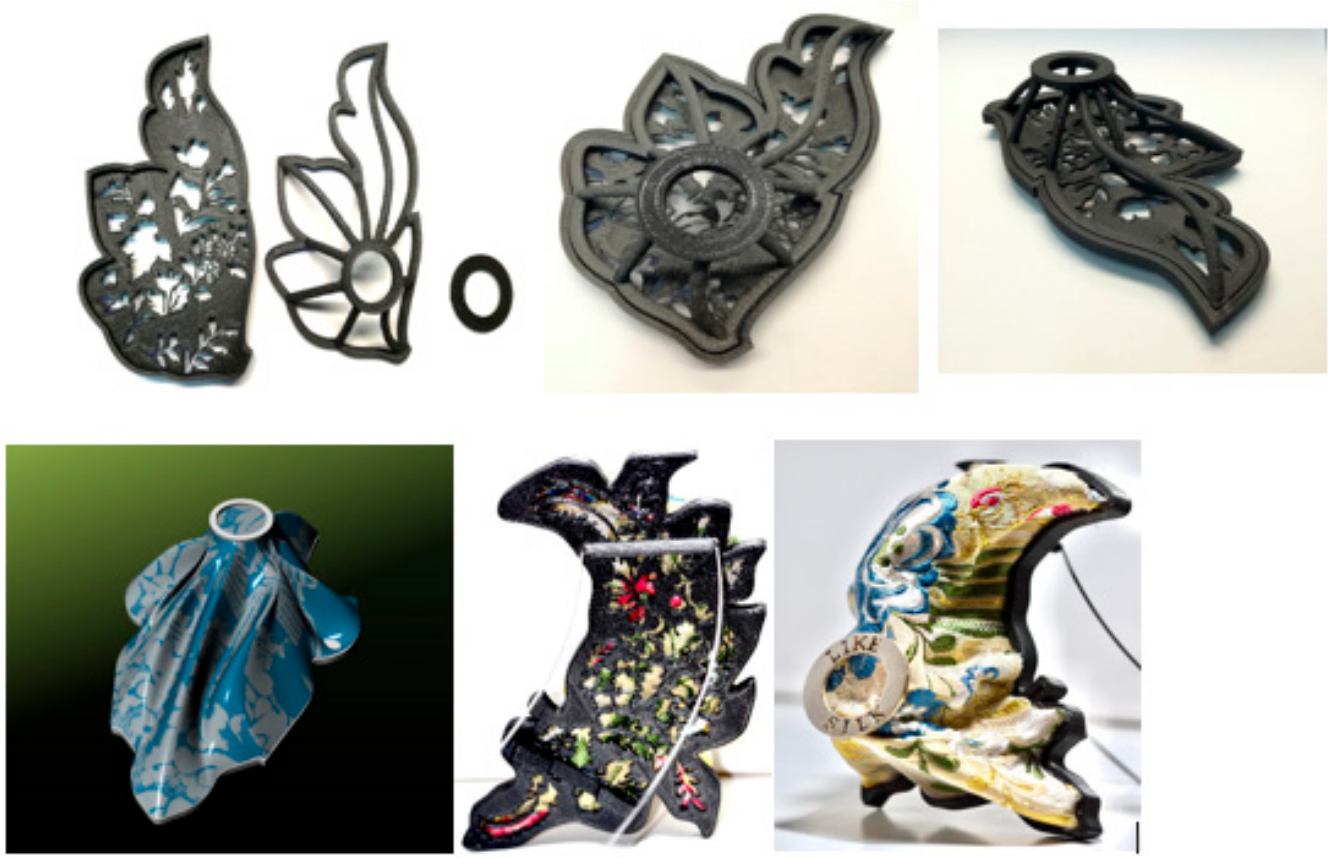

Figure 9. Different steps in the production of brooches for the jewelry subject at EASD Valencia, inspired by the SILKNOW project within the Like Silk project carried out by the students (Belén Campos, María Candela Soto, Chang Hsin I, María Fe Cortez, Carlotta De Paz Villegas, Ginny Lantiguas, Debora Mir, Cindy Valencia) under the direction of Professor José Marín.

The second project involved the students of Professor Mar Moya's fashion project (Figures 10 and 11). In this case, the project took two years. In the first year the workshops focused on the European silk history and the Silk Road, generating projects associated with the manufacturing processes of silk or inspired by cultural exchanges. In the second contact, the workshops consisted, as in the project Like Silk, of the sample of the repertoire of images associated with the cultural heritage of silk through the tools developed by the project. A visit to GARÍN1820 was also established for young designers to come into contact with this living heritage, part of their culture. Understanding the historical motifs of silk, the traditional weaving techniques and the understanding of the hand looms of the 19th century Jacquards that are still active in this small craft were the main reasons for the inspiration developed by the students in the executed projects. This project is part of a fourth degree course in design, called Fashion Workshop, at EASD Valencia. In this subject, students coordinated by the teacher must carry out a project in close relationship with the outside world: museums, cultural institutions, creative industries, research projects, etc. Since 2018, concerning the appointment of Valencia as the capital city of silk (2016-2017) and collaboration with SILKNOW, the students began their first projects related to the Silk Road. The proposal sought to generate creativity based on inspiration in the material elements associated with silk and its production techniques, from the cocoon of silk to emblematic buildings and spaces such as the Lonja de Valencia, a World Heritage Site by UNESCO. These projects resulted in an exhibition in 2018, at the Ateneo Mercantil in Valencia, under the title "Re-designing the Silk Road". The main idea was to bring students closer to a better understanding of the history and cultural heritage linked to the European silk tradition and the history of historical international exchanges. This project continued in 2019 with projects inspired by the traditional textile and clothing traditions of different countries along the Silk Road.

In the 2019-2020 academic year, the project of Fashion Workshop (Figures 12 and 13) with SILKNOW was to know in-depth the historical designs of European silk, as well as the different processes of weaving, such as satin, damascus, espolin, velvet, etc., through tools such as the thesaurus and the virtual loom developed by the project. Creative designs focused on redesigning 18th century weaving and technical models. For this purpose, the structure of the projects was based on: 
1. An historical study, 2. Shapes, 3. Function of the designs, 4. Use, 5. Structure of the garments, 6. Finish first idea, 7. Brainstorm, 8. Project development and implementation. The main objective of this collaboration was to seek inspiration in the heritage elements of the history of silk and to create something new and innovating in technology. Each student prepared two portfolios, the first with forms and structures, and the second with colors and textures where historical designs and silk techniques were the main creative incentive, especially floral motifs, which were very common in the 18th century. Then, the sketching process began, perhaps the most creative one, and one of the sketches was selected for technical implementation, always with ecological and sustainable materials. Once the prototype was made, it was photographed and exhibited.

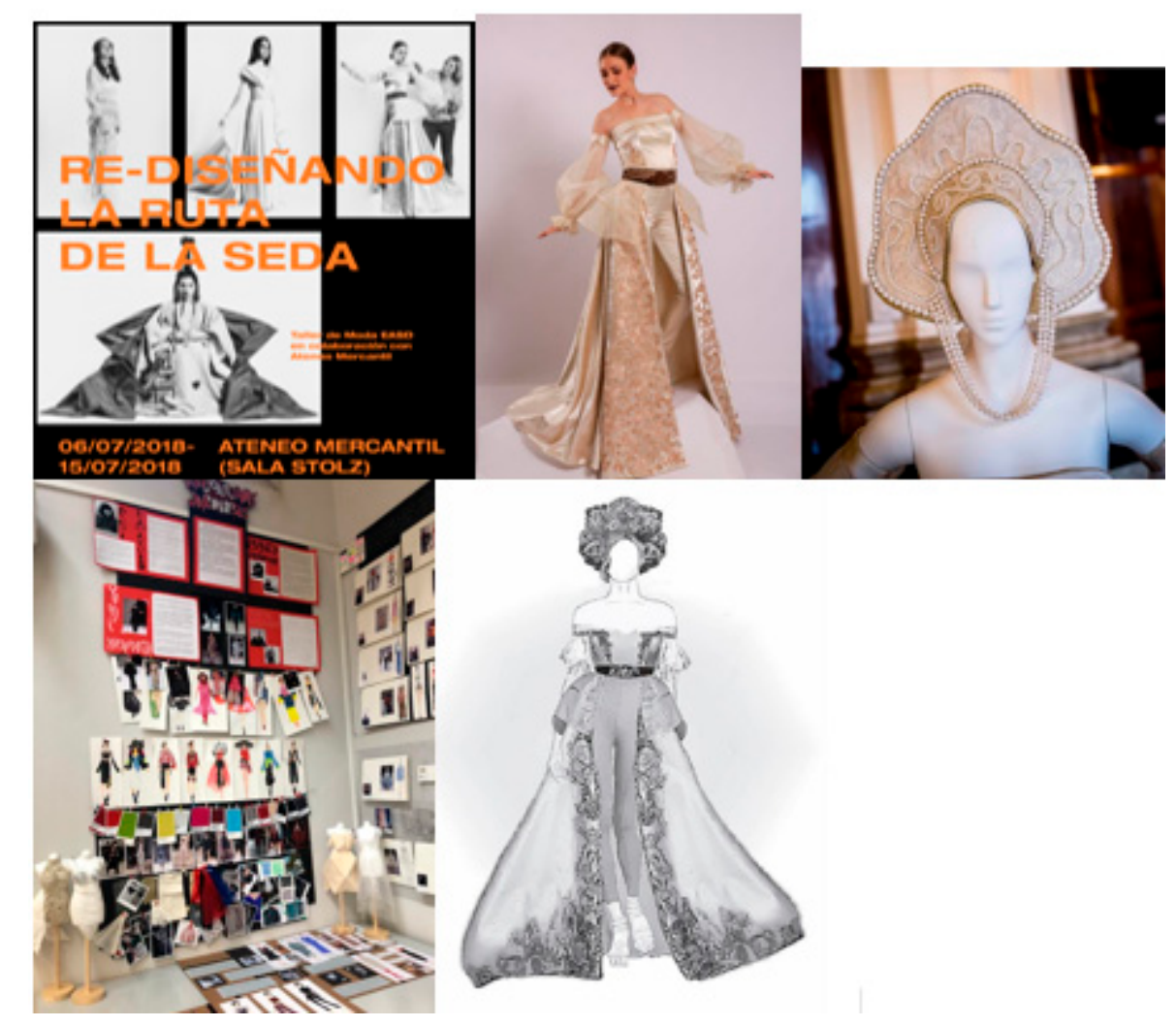

Figure 10. Creative process and final result of the exhibition Re-designing the Silk Road (2018), with some examples of the results of the projects of the students of the Fashion Workshop of the EASD, under the direction of Mar Moya. The project in the image was developed by the student Alejandro Forrat.

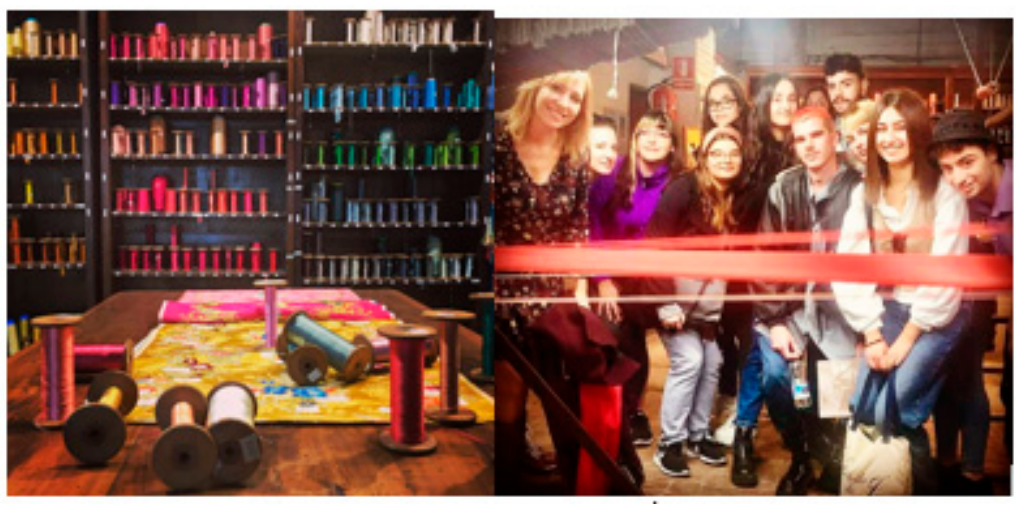

Figure 11. Visit of the students of Fashion Workshop to the Garín factory 1820. 


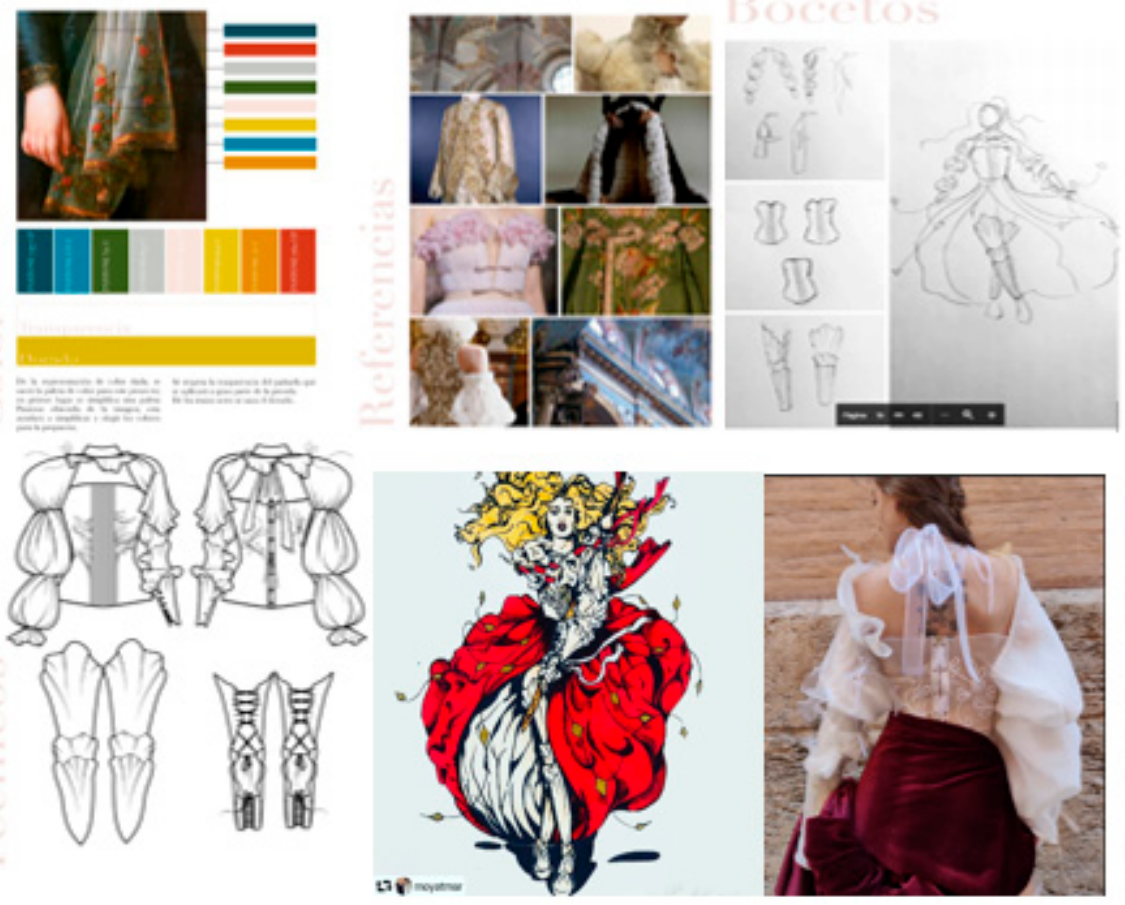

Figure 12. Project by the student Carla Grau, that shows her creative process, from early sketches to her dress.

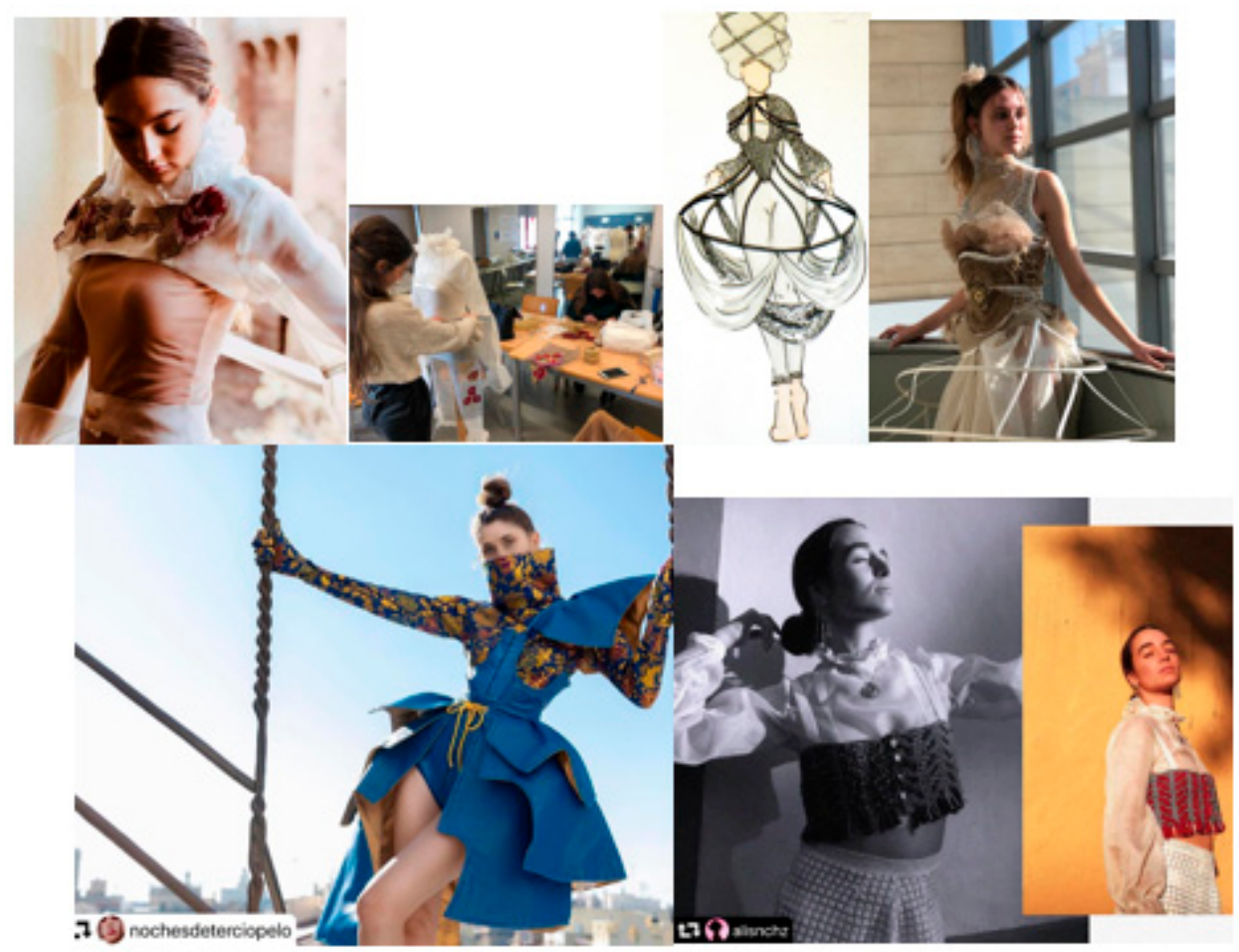

Figure 13. Several examples of designs created in the 2019-2020 course at the Fashion Workshop inspired by 18th century European silk designs. The projects in image were developed by the students Yolanda Munera, Quique Guinart, Aitana Lorenzo and Alicia Sánchez.

The result of these educational projects of future creatives and designers has been very helpful. In particular, it has been indicative of the enormous potential that the stewardship and understanding 
of cultural heritage has for the development and innovation of creative industries and the promotion of young talent.

\section{Conclusions}

As seen in the discussion section, we discussed how theoretical approaches related to the aforementioned creative industries [3-9,20,25-29,32,37] and the international and European frameworks $[1,17,22,23,40-44,47,57]$ can be applied to cultural heritage, using it as catalyst for sustainable development as well as creativity. As mentioned, cultural heritage, especially ones linked to artisanal crafts, have a big impact on local identity, but, at the same time, have a close dialogue with creative industries [57]. Silk and its history in Europe has had a strong impact on knowledge, technique, design, creativity and urban and economic development. In SILKNOW, we used this tradition to make an impact on current creative industries. In order to do so, we went through several channels: museums and heritage sites, education in design schools, textile industries and image recognition for modern designers. Other authors have dealt with these issues in other countries such as Nigeria [107], where the use of traditionally made textiles has been used as a development for local communities. In Europe, we have taken into account the already mentioned Textiel Museum [85], but also the Italian case of the Textile Museum of Prato [108], which is striving to preserve its industrial heritage at the time as they are developing a sustainable system where the Prato community can be involved. Other examples can be found in $[109,110]$. These examples have shown how SILKNOW uses silk heritage in every dimension (tangible and intangible) to develop creativity and how this heritage contributes to creative processes. As [111] states, heritage has a double-edge effect "while bestowing competitive advantages and favouring the development of creativity, do orient development along a given path, promoting a certain kind of creativity that may lead to lock-in effects, and build obstacles in the way of development".

Author Contributions: Conceptualization, E.A.P.; methodology, E.A.P.; software, M.D.P., D.C., M.D., D.W.; validation, M.D.P., D.C., M.D., D.W. and F.R.; formal analysis, E.A.P., M.D.P., M.d.M.G.S., A.L.M., F.R., M.D.P., G.L.C., M.V., M.d.M.M.T., J.M.R., P.V, M.P.; investigation, E.A.P., M.D.P., M.d.M.G.S., A.L.M., F.R., M.D.P., D.C., M.D., D.W., G.L.C., M.V., M.d.M.M.T., J.M.R., P.V., M.P.; resources, M.d.M.M.T., J.M.R. and A.L.M.; data curation, F.R., M.D.P., M.d.M.G.S., A.L.M., D.C., M.D., D.W.; writing—original draft preparation, M.d.M.G.S., A.L.M., E.A.P.; writing-review and editing, M.d.M.G.S., A.L.M., E.A.P., F.R., D.W.; visualization, E.A.P.; supervision, E.A.P., M.d.M.G.S., funding acquisition, E.A.P., M.D.P., M.d.M.G.S., A.L.M., F.R., M.D.P., D.C., D.W., G.L.C., M.V. and P.V. All authors have read and agreed to the published version of the manuscript.

Funding: The research leading to these results is in the frame of the "SILKNOW. Silk heritage in the Knowledge Society: from punched cards to big data, deep learning and visual/tangible simulations" project, which has received funding from the European Union's Horizon 2020 research and innovation program under grant agreement No. 769504.

Conflicts of Interest: The authors declare no conflict of interest.

\section{References}

1. PNUD, UNESCO. Informe Sobre la Economía Creativa 2013. Available online: https://unesdoc.unesco.org/ark: /48223/pf0000230576 (accessed on 10 September 2020).

2. Creative Industries Task Force. The Creative Industries Mapping Report; HMSO: London, UK, 1998.

3. De Propris, L.; Chapain, C.; Cooke, P.; MacNeill, S.; Mateos-Garcia, J. The Geography of Creativity. Interim Report; NESTA: London, UK, 2009.

4. Lazzeretti, L. The creative capacity of culture and the new creative milieu. In A Handbook of Industrial Districts; Becattini, G., Bellandi, M., De Propris, L., Eds.; Edward Elgar: Cheltenham, UK, 2009; pp. 281-294.

5. Hesmondhalgh, D. The Cultural Industries; Sage: London, UK, 2002.

6. O'Connor, J. Creative industries: A new direction? Int. J. Cult. Policy 2009, 15, 387-402. [CrossRef]

7. Zuindeau, B. Développement durable et territoires. In Ressources Naturelles et Culturelles, Milieux et Développement Local; Camagni, R., Maillat, D., Matteaccioli, A., Eds.; EDES: Neuchâtel, France, 2004; pp. 1-5.

8. Flew, T.; Cunningham, S. Creative Industries after the First Decade of Debate. Inf. Soc. 2010, 26, 113-123. [CrossRef] 
9. Jeffcutt, P. Management and the creative industries. Stud. Cult. Organ. Soc. 2007, 6, 123-127.

10. Alba, E.; Gaitán, M.; Sebastián, S.; León, A. SILKNOW, tejiendo el pasado hacia el futuro. Datatèxtil 2020, 40, $1-7$.

11. Alba Pagán, E.; Fernández, M.; Gaitán, M.; León, A.; Portalés, C.; Sebastián, J.; Sevilla, J. Technological tools for the conservation of silk Heritage: Improving the conservation of European religious textile cultural Heritage. In Proceedings of the 11th European on Religious Art, Restoration and Conservation (ESRARC 2019), Valencia, Spain, 11-13 April 2019; Vazquez, M., Rusu, I., Pelosi, C., Lanteri, L., Lo Monaco, A., Apostolescu, N., Eds.; Kermes Books: Torino, Italy, 2019; pp. 150-156.

12. Gaitán, M.; Alba, E.; León, A.; Pérez, M.; Sevilla, J.; Portalés, C. Towards the Preservation and Dissemination of Historical Silk Weaving Techniques in the Digital Era. Heritage 2019, 2, 1892-1911. [CrossRef]

13. Alba, E.; Pitarch, M.D.; Sebastian, J.; Arnandis, R.; Portalés, C.; Gaitán, M. Innovación social en patrimonio cultural y museos de la seda en Europa: Una mirada conectada con las industrias creativas. In Proceedings of the International Conference on Regional Science. Hacia un Modelo Económico más Social y Sostenible, XLVI Conferencia Internacional de Ciencia Regional, Valencia, Spain, 21-23 November 2019; Boix, R., Ed.; Asociación Española de Ciencia Regional: Valencia, Spain, 2019.

14. Portalés, C.; Sebastián, J.; Alba, E.; Sevilla, J.; Gaitán, M.; Ruiz, P.; Fernández, M. Interactive Tools for the Preservation, Dissemination and Study of Silk Heritage-An Introduction to the SILKNOW Project. MTI 2018, 2, 28. [CrossRef]

15. Bulletin L'archéologie Industrielle en France. Patrimoine, Technique, Mémoire. n 44, June 2004, special issue on Silk cultural heritage. Available online: https://www.icomos.org/centre_documentation/bib/industrialheritage. pdf (accessed on 29 September 2020).

16. European Textiles and Fashion: Facts \& Figures. Available online: https://bit.ly/3h6WJux (accessed on 10 June 2020).

17. European Commission. Promover los Sectores de la Cultura y la Creación para el Crecimiento y el Empleo en la UE; COM 537 final, 26.9.2012; European Union: Brussels, Belgium, 2012. Available online: https://eur-lex.europa. eu/legal-content/ES/TXT/PDF/?uri=CELEX:52012DC0537\&from=EN (accessed on 29 September 2020).

18. Jokilehto, J. Valores patrimoniales y valoración. Conversaciones 2017, 1, 20-32.

19. Mendes, S. Reconsiderando la evaluación de los bienes culturales. Conversaciones 2016, 60-74. Available online: https://www.academia.edu/27253544/Conversaciones_con_Jukka_Jokilehto_No_2_(accessed on 29 September 2020).

20. Throsby, D. Cultura, economía y desarrollo sustentable. In Cultura y Economía I; Consejo Nacional de la Cultura y las Artes: Santiago de Chile, Chile, 2012; pp. 55-62.

21. Greffe, X. La Valeur Economique du Patrimoine. La Demande et l'offre de Monuments; Anthropos: París, France, 1990; pp. 154-196.

22. OECD. Culture and Local Development; OECD: Paris, France, 2005.

23. OECD-ICOM. Cultura y Desarrollo Local: Maximizar el Impacto. Una Guía Para Gobiernos Locales, Comunidades y Museos; OECD: Paris, France, 2010.

24. Ciudades y Gobiernos Locales Unidos. Agenda 21 Para la Cultura; Organización de Estados Iberoamericanos para la Educación, la Ciencia y la Cultura: Barcelona, Spain, 2008.

25. Boix, R.; Capone, F.; De Propris, L.; Lazzeretti, L.; Sanchez, D. Comparing creative industries in Europe. Eur. Urban Reg. Stud. 2016, 23, 935-940. [CrossRef]

26. Müller, K.; Rammer, C.; Trüby, J. The role of creative industries in industrial innovation. Innovation 2009, 11, 148-168. [CrossRef]

27. Lazzeretti, L. Creative Industries and Innovation in Europe: Concepts, Measures and Comparative Case Studies; Routledge: London, UK, 2012.

28. Klein, J.L.; Tremblay, D.G. Cultural creation and social innovation as the basis for building a cohesive city. In Handbook on the Geographies of Innovation; Edward Elgar Publishing: Cheltensham, UK, 2016.

29. Romanelli, M.; Zbuchea, A. Knowledge-based social innovation for cultural endeavours revitalising urban structures. Int. J. Knowl. Dev. 2020, 11, 98-121. [CrossRef]

30. Guasch, A.M. La memoria del otro en la era global. Revista de Estudios Globales y Arte Contemporáneo 2014, 2, $81-91$.

31. Appadurai, A. Minorities and the Production of Daily Pace. Interview with Arjun Appadurai. In Feelings Are Always Local; Brouwer, J., Mulder, A., Eds.; NAI Publishers: Rotterdarm/Amsterdam, The Netherlands, 2004. 
32. Bakhski, H.; McVittie, E.; Simmie, J. Creating Innovation. Do the Creative Industries Support Innovation in the Wider Economy? NESTA Research Report, Nesta. 2008. Available online: https://media.nesta.org.uk/ documents/creative-innovation.pdf (accessed on 29 September 2020).

33. Echevarría, J. Industrias Culturales y Creativas. Perspectivas, Indicadores y Casos; Sinnergiak Social Innovation: Donostia, Spain, 2016.

34. UN. La Convención Sobre la Protección y la Promoción de la Diversidad de las Expresiones Culturales; UN: New York, NY, USA, 2005. Available online: http://www.unesco.org/new/es/culture/themes/cultural-diversity/ cultural-expressions/the-convention/convention-text (accessed on 29 September 2020).

35. UNWTO/UNESCO. Silk Road Heritage Corridors Tourism Strategy Project. Available online: https: //bit.ly/2Dsndso (accessed on 10 June 2020).

36. Department for Culture, Media and Sport. Creative Industries Task Force; DCMS: London, UK, 2001.

37. Florida, R. The Rise of the Creative Class; Basic Books: New York, NY, USA, 2002.

38. Commonwealth of Australia, Department of Communications and the Arts. Creative Nation: Commonwealth Cultural Policy; Australian Government Publisher, Department of Communications and the Arts: Canberra, Australia, 1994.

39. KEA European Affairs. Business Innovation Support Services for Creative Industries, Report for the European Commission; DG Enterprise and Industry: UK, March 2010. Available online: https://silo.tips/download/ business-innovation-support-services-for-creative-industries-february-2010 (accessed on 29 September 2020).

40. UNCTAD (Conferencia de las Naciones Unidas sobre Comercio y Desarrollo). Creative Economy: Report 2008; ONU: New York, NY, USA, 2008.

41. UNCTAD (Conferencia de las Naciones Unidas sobre Comercio y Desarrollo). Creative Economy: Report 2010; ONU: New York, NY, USA, 2010.

42. European Commission. Europe 2020 Flagship Initiative Innovation Union; European Union: Brussels, Belgium, 2010.

43. European Commission. Libro Verde: Liberar el Potencial de las Industrias Culturales y Creativas; 27.4.2010 COM, Bruselas, 183 final; European Union: Brussels, Belgium, 2010.

44. KEA European Affairs. The Economy of Culture in Europe. Report Prepared for the European Commission Directorate-General for Education and Culture; Media 23Group-Turku School of Economic and Business Administration, MKW Wirtschaftsforschung GMbH: Brussels, Belgium, 2006.

45. Bilbao Lan Ekintza. Estudio Sobre el Potencial de las Industrias Creativas en Bilbao. 2009. Available online: https://www.bilbao.eus/cs/Satellite?blobcol=urldata\&blobheader=application \%2Fpdf\%3Bcharset $\%$ 3DUTF-8\&blobkey=id\&blobnocache=true \&blobtable=MungoBlobs\&blobwhere $=1273769639268 \&$ ssbinary=true (accessed on 29 September 2020).

46. Ministerio de Cultura y Deporte (Dirección General de industrias culturales y del libro). Plan de Fomento de las Industrias Culturales y Creativas; Ministerio de Cultura y Deporte: Madrid, Spain, 2018.

47. European Parliament. Report on a Coherent EU Policy for Cultural and Creative Industries. (2016/2072(INI)). 2016. Available online: https://eur-lex.europa.eu/legal-content/EN/TXT/?uri=CELEX\%3A52016IP0486 (accessed on 10 September 2020).

48. Howkins, J. The Creative Economy: How People Make Money from Ideas; Penguin: London, UK, 2001.

49. Muñoz Cosme, A. Patrimonio cultural e innovación. Construir el futuro de nuestro presente. Revista Patrimonio Cultural de España. Patrimonio e Innovación 2010, 4, 9-14.

50. Bonilla Arjona, J.; Maroto Illera, R.; Cabrerizo Sanz, C. Las Industrias Culturales y Creativas. Un Sector Clave de la Nueva Economía; Fundación Ideas: Madrid, Spain, 2012.

51. Boix, R.; Lazzeretti, L. Las industrias creativas en España; una panorámica. Investigaciones Regionales 2011, 22, 181-206.

52. Franch Benavent, R. La producción de seda en el País Valenciano durante el siglo XVIII: Distribución geográfica y evolución. Historia Agraria: Revista de Agricultura e Historia Rural 1994, 8, 67-98.

53. Franch Benavent, R. El abastecimiento de materias primas en la industria textil española del siglo XVIII. In Industria y Época Moderna; Editorial Actas: Madrid, Spain, 2000; pp. 63-94.

54. Franch Benavent, R. La seda en la Valencia moderna: De la expansión productiva y manufacturera del siglo XVI al periodo de esplendor del siglo XVIII. In Las Rutas de la Seda en la Historia de España y Portugal; Universitat de València: València, Spain, 2017; pp. 129-161. 
55. López Terrada, M.J.; Alba, E. Pintores y ornatos para los Tejidos de seda en la Ilustración y la Academia valenciana de Bellas Artes. Quad. Filol. 2018, 23, 117-142. [CrossRef]

56. Comissió de les Arts. Informe Sobre el Legado de la Casa Insa y un Posible Museo de la Indumentaria y los Disfraces; Aprobado en el Pleno del 31 de enero de 2011; Consell Valencià de Cultura: Valencia, Spain, 2011.

57. UNESCO. Existe un Fuerte Vínculo Entre la Inversión en las Industrias Culturales y Creativas y el Desarrollo Sostenible; Entrevista con Sabrina Ho.: 2018. Available online: https://es.unesco.org/creativity/news/existefuerte-vinculo-entre-inversion-en-las-industrias (accessed on 29 September 2020).

58. Técnicas Artesanales Tradicionales. Available online: https://bit.ly/31W51Rm (accessed on 25 June 2020).

59. Cunningham, S.D.; Higgs, P. Measuring creative employment: Implications for innovation policy. Innov. Manag. Policy Pract. 2009, 11, 190-200. [CrossRef]

60. Design 21. Available online: https://bit.ly/32VZ0DJ (accessed on 25 June 2020).

61. Sello de Excelencia a la Artesanía. Available online: https://bit.ly/2Z6sj5s (accessed on 25 June 2020).

62. Maestro d'Arte e Metiere. Available online: https://bit.ly/2F4jge4 (accessed on 25 June 2020).

63. Ministerio de Industria, Comercio y Turismo. Available online: https://bit.ly/3556KpF (accessed on 25 June 2020).

64. Centro de Artesanía. Available online: https://bit.ly/354sq4Z (accessed on 25 June 2020).

65. Dunkin, L. Crafts and Conservation: Synthesis Report for ICCROM; ICCROM: Rome, Italy, 2001.

66. Archer, B. Design as a discipline. Des. Stud. 1979, 1, 20. [CrossRef]

67. IMATEX. Available online: https://bit.ly/3bpSXei (accessed on 7 July 2020).

68. Museum of Fine Arts of Boston. Available online: https://bit.ly/2EPV6nX (accessed on 7 July 2020).

69. Krizhevsky, A.; Sutskever, I.; Hinton, G.E. ImageNet Classification with Deep Convolutional Neural Networks. Advances in Neural Information Processing Systems. Available online: https://papers.nips.cc/paper/4824imagenet-classification-with-deep-convolutional-neural-networks (accessed on 29 September 2020).

70. Xiao, Z.; Liu, X.; Wu, J.; Geng, L.; Sun, Y.; Zhang, F.; Tong, J. Knitted fabric structure recognition based on deep learning. J. Text. Inst. 2018, 109, 1217-1223. [CrossRef]

71. He, K.; Zhang, X.; Ren, S.; Sun, J. Identity mappings in deep residual networks. In European Conference on Computer Vision, Amsterdam, The Netherlands, 8-16 October 2016; Springer: Berlin/Heidelberg, Germany, 2016; pp. 630-645.

72. Iqbal Hussain, M.A.; Khan, B.; Wang, Z.; Ding, S. Woven Fabric Pattern Recognition and Classification Based on Deep Convolutional Neural Networks. Electronics 2020, 9, 1048. [CrossRef]

73. Howard, A.G.; Zhu, M.; Chen, B.; Kalenichenko, D.; Wang, W.; Weyand, T.; Andreetto, M.; Adam, H. Mobilenets: Efficient convolutional neural networks for mobile vision applications. arXiv 2017, arXiv:1704.04861.

74. Puarungroj, W.; Boonsirisumpun, N. Recognizing hand-woven fabric pattern designs based on deep learning. In Advances in Computer Communication and Computational Sciences; Springer: Singapore, 2019; pp. 325-336.

75. Meng, S.; Ruru, P.; Weidong, G.; Jian, Z.; Jingang, G.; Wentao, H. A multi-task and multi-scale convolutional neural network for automatic recognition of woven fabric pattern. J. Intell. Manuf. 2020, 5, 1-15. [CrossRef]

76. Li, Y.; Zhao, W.; Pan, J. Deformable patterned fabric defect detection with fisher criterion-based deep learning. IEEE Trans. Autom. Sci. Eng. 2016, 14, 1256-1264. [CrossRef]

77. Gao, C.; Zhou, J.; Wong, W.K.; Gao, T. Woven fabric defect detection based on convolutional neural network for binary classification. In Proceedings of the International Conference on Artificial Intelligence on Textile and Apparel, Hong Kong, China, 3-6 July 2018; pp. 307-313.

78. Belhi, A.; Bouras, A.; Foufou, S. Towards a hierarchical multitask classification framework for cultural heritage. In Proceedings of the 2018 IEEE/ACS 15th International Conference on Computer Systems and Applications (AICCSA), Aqaba, Jordan, 28 October-1 November 2018; pp. 1-7.

79. Dorozynski, M.; Wittich, D.; Rottensteiner, F. Deep Learning zur Analyse von Bildern von Seidenstoffen für Anwendungen im Kontext der Bewahrung des kulturellen Erbes. In Proceedings of the 39th Scientific-Technical Annual Meeting of the German Society of Photogrammetry, Remote Sensing and Geoinformation (DGPF), Vol. 28 of the Publications of the DGPF, Wien, Austria, 10-11 December 2019; pp. 387-399.

80. Dorozynski, M.; Clermont, D.; Rottensteiner, F. Multi-task deep learning with incomplete training samples for the image-based prediction of variables describing silk fabrics. ISPRS Ann. Photogramm. Remote Sens. Spat. Inf. Sci. IV-2/W6 2019, 4, 47-54. [CrossRef]

81. Green, N. On the move: Technology, mobility, and the mediation of social time and space. Inf. Soc. 2002, 18, 281-292. [CrossRef] 
82. Kéfi, H.; Pallud, J. The role of technologies in cultural mediation in museums: An Actor-Network Theory view applied in France. Mus. Manag. Curatorship 2011, 26, 273-289. [CrossRef]

83. Fajardo, C. Aproximación a los cambios operados en la estética de la era global. In Real/Virtual en la Estética y la Teoría de las Artes; Marchán, S., Ed.; Paidós: Barcelona, Spain, 2006; pp. 287-307.

84. Hernández-Hernández, F. El patrimonio Cultural: La Memoria Recuperada; Trea: Gijón, Spain, 2002.

85. TEXTIELMUSEUM. Available online: https://bit.ly/3i5gMe8 (accessed on 18 July 2020).

86. Fondazione Lisio. Available online: https://bit.ly/3ichEh7 (accessed on 18 July 2020).

87. GARIN 1820 S.A. Available online: http://garin1820.com/ (accessed on 18 July 2020).

88. Luigi Bevilacqua. Available online: https://www.luigi-bevilacqua.com/ (accessed on 18 July 2020).

89. Asociación de Creadores Textiles de Madrid. Available online: http://creadorestextiles.org/ (accessed on 18 July 2020).

90. Gambi, S. La Magia Dell'upcycling: Trasformare gli Scarti in Qualcosa di Unico. Available online: https: //bit.ly/2F0JvSN (accessed on 28 May 2020).

91. ANSA. Nasce Resilk Dagli Scarti la Nuova Seta. Available online: https://bit.ly/354ZA4I (accessed on 28 May 2020).

92. Signorini, E. Mantero, Sostenibilità Come Visione, 28 Agosto 2019. Available online: https://bit.ly/3h5GRII (accessed on 28 May 2020).

93. Spolini, N. Mantero Presenta Resilk la Seta Rigenerata. Available online: https://bit.ly/3gUi7CR (accessed on 12 June 2020).

94. Crivelli, G. Mantero dà una Seconda vita Alla Seta con il Progetto Resilk. Available online: https: //bit.ly/2F6iQ6G (accessed on 4 June 2020).

95. Maci, F. ReEVOLUTION, la Seta ha Nuova vita "La Tessitura" Presenta ReSilk, la Rivoluzione/Evoluzione del Riciclo, Settembre 2006. in Natural Street. Available online: https://bit.ly/3jMIEUI (accessed on 4 June 2020).

96. Adnkronos, Mantero Presenta Resilk, Progetto per dare Nuova vita alla Seta. Available online: https: //bit.ly/3hTKW3L (accessed on 28 May 2020).

97. Maalsen, S.; McLean, J. Cultural turn. In Encyclopedia of Human Geography; Elsevier: Amsterdam, The Netherlands, 2020; pp. 117-121.

98. Florida, R. The economic geography of talent. Ann. Assoc. Am. Geogr. 2002, 92, 743-755. [CrossRef]

99. Boix, R.; Lazzeretti, L.; Capone, F.; De Propris, L.; Sánchez, D. The geography of creative industries in Europe: Comparing France, Great Britain, Italy and Spain. In Creative Industries and Innovation in Europe; Routledge: London, UK, 2013; pp. 23-44.

100. Caragliu, A.; Del Bo, C.F. Smart innovative cities: The impact of Smart City policies on urban innovation. Technol. Forecast. Soc. Chang. 2019, 142, 373-383. [CrossRef]

101. Peck, J. Social innovation... at the limits of neoliberalism. In Pour une Nouvelle Mondialisation: Le défi D'innover; Presses de 1'Université du Québec: Québec, QC, Canada, 2013; pp. 11-30.

102. Lees, L.; Slater, T.; Wyly, E. Gentrification; Routledge: London, UK, 2013.

103. Cocola-Gant, A. Tourism gentrification. In Handbook of Gentrification Studies; Edward Elgar Publishing: Cheltensham, UK, 2018; pp. 281-293.

104. Línea del Tiempo. Available online: https://bit.ly/2QXNrGc (accessed on 8 July 2020).

105. SILKMEMORY. Available online: https://bit.ly/2GuRLLn (accessed on 8 July 2020).

106. Escola d'Art i Superior Disseny de València. Available online: http://www.easdvalencia.com/ (accessed on 9 July 2020).

107. Maiwada, S.A.; Dutsenwai, A.; Waziri, M.Y. Cultural industries and wealth creation: The case of traditional textile industry in Nigeria. Am. Int. J. Contemp. Res. 2012, 2, 159-165.

108. Daria, S.; Varra, L. The organisation of a districtual museum: The Textile Museum of Prato, preserving an industrial heritage and developing a sustainable system. Engineering 2013, 289-296. Available online: https://www.semanticscholar.org/paper/The-organisation-of-a-districtual-museum\%3A-the-of-anDaria-Lucia/b54779bee46db9920275280f4e185dcc2ecfe8fb (accessed on 29 September 2020).

109. De-Miguel-Molina, B.; Hervas-Oliver, J.L.; Boix, R.; Maria De-Miguel-Molina, M. The Importance of Creative Industry Agglomerations in Explaining the Wealth of European Regions. Eur. Plan. Stud. 2002, 20, 1263-1280. [CrossRef] 
110. Bertacchini, E.; Borrione, P. The Geography of the Italian Creative Economy: The Special Role of the Design and Craft-based Industries. Reg. Stud. 2013, 47, 135-147. [CrossRef]

111. Barrère, C. Heritage as a basis for creativity in creative industries: The case of taste industries. Mind Soc. 2013, 12, 167-176. [CrossRef]

(C) 2020 by the authors. Licensee MDPI, Basel, Switzerland. This article is an open access article distributed under the terms and conditions of the Creative Commons Attribution (CC BY) license (http://creativecommons.org/licenses/by/4.0/). 